NBER WORKING PAPER SERIES

\title{
REGULATORY REFORM AND RISK-TAKING: REPLACING RATINGS
}

\author{
Bo Becker \\ Marcus Opp \\ Working Paper 19257 \\ http://www.nber.org/papers/w19257
NATIONAL BUREAU OF ECONOMIC RESEARCH
1050 Massachusetts Avenue
Cambridge, MA 02138
July 2013

An earlier version of this paper was entitled "Replacing Ratings." We thank Andrew Cohen, Richard Cantor, Jess Cornaggia, Andrew Ellul, Jerome Fons, Andra Ghent, John Griffin, Dwight Jaffee, Anastasia Kartasheva, Eric Kolchinsky, Terrance Odean, Matti Peltonen, Tad Philipp, Joshua Rauh, Farzad Saidi, Erik Stafford, Richard Stanton, Terri Vaughan, and Nancy Wallace as well as seminar participants in Stockholm, Berkeley, Rotterdam, ECB, Maastricht, the European Winter Finance Conference, the NBER summer institute for credit ratings, the Bundesbank and the Bank of Spain for comments and suggestions, Jack He, Jun Qian and Phil Strahan as well as Pab Jotikasthira for sharing data, as well as Kevin Garewal and Andrea Schulman for excellent research assistance. The views expressed herein are those of the authors and do not necessarily reflect the views of the National Bureau of Economic Research.

NBER working papers are circulated for discussion and comment purposes. They have not been peerreviewed or been subject to the review by the NBER Board of Directors that accompanies official NBER publications.

(C) 2013 by Bo Becker and Marcus Opp. All rights reserved. Short sections of text, not to exceed two paragraphs, may be quoted without explicit permission provided that full credit, including $\odot$ notice, is given to the source. 
Regulatory reform and risk-taking: replacing ratings

Bo Becker and Marcus Opp

NBER Working Paper No. 19257

July 2013, Revised September 2014

JEL No. G22,G24,G28

\begin{abstract}
$\underline{\text { ABSTRACT }}$
We analyze a reform of insurance companies' capital requirements for mortgage-backed securities. First, credit ratings were replaced as inputs to capital regulation. Second, the redesigned system ensures capital buffers sufficient to withstand expected losses, but insufficient to protect against adverse outcomes. Many bonds are now treated as riskless and require minimal capital. By 2012, aggregate capital requirements for mortgage-backed securities have been reduced from \$19.36bn (had the previous system been maintained) to $\$ 3.73 \mathrm{bn}$. Exploiting that the change did not affect other asset classes, we document that insurers' risk taking was distorted and increased in response to the new regulation.
\end{abstract}

Bo Becker

Stockholm School of Economics

Box 6501

11383 Stockholm

Sweden

beckerbobo@gmail.com

Marcus Opp

UC Berkeley

Haas School of Business

Student Services Bldg. \#1900

Berkeley, CA 94720-1900

mopp@haas.berkeley.edu 
The recent financial crisis has triggered a broad push toward increased regulation of the financial sector, and a vigorous debate about how to best implement this overhaul. At the heart of the debate is the issue of capital requirements. In particular, Admati et al. (2013) and Thakor (2014) argue that financial institutions should be subject to significantly higher capital requirements in order to mitigate risk-shifting incentives and increase the stability of the financial sector. On the other hand, Ordonez (2013) and Plantin (2014) argue that increased regulation of banks may push intermediation into unregulated entities (e.g., the "shadow banking" system). However, understanding what capital requirements ought to be is not sufficient for understanding policy and giving advice. Reforms may reflect other forces than the long run "first best," such as industry pressure (Stigler, 1971), conflicts of interest (Zingales, 2013), distorted incentives for regulators (Leaver, 2009) or capacity constraints on regulatory activity. Which of these forces have influenced recent regulation is not well understood.

One way to learn about forces that influence contemporary rulemaking is to examine particular regulatory episodes. The recent financial crisis prompted large reform pushes across all advanced economies and touching most parts of the financial system. This has generated a large set of events to study, including the one we in analyze in this paper: a reform of the capital requirements for U.S. insurers in 2009 and 2010. This event is particularly interesting, for two reasons. First, it constituted an abrupt and distinct change in capital requirements, which is a key policy choice. Second, the reform was deep enough to be important to the industry, impacting all insurance holdings of mortgage-backed securities, but narrow enough that we can use other, unaffected, asset classes as a benchmark. The design of the reform allows fairly clean identification of how the industry's risk-taking responded to its changed regulatory incentives. In brief, capital requirements were lowered, especially for risky MBS. Insurers appear to have responded by assuming substantially more risk in new acquisitions of MBS (but not in other asset classes). Apart from delineating the response to a broad change in capital requirements, the event also sheds some light on the forces influencing the reform process, how industry interests are weighed, and on how tradeoffs between the short and long term are perceived by the regulator.

In 2009, the National Association of Insurance Commissioners (NAIC), the coordinating body for state level regulators' overhauled the system for capital requirements for mortgage-backed securities (MBS). ${ }^{1}$ Structured securities represent $18.5 \%$ of insurers' assets (MBS constituted about half of this), second only to corporate bonds and ahead of government bonds. ${ }^{2}$ Because many assets in insurance companies' portfolios are very safe (e.g., treasuries or highly rated corporate bonds), structured products play a very important role for capital requirements. During 2009, MBS (alongside other structured securities) were widely downgraded. ${ }^{3}$ This meant that insurers' capital requirements, which were mechanically tied to ratings (see Opp, Opp,

\footnotetext{
${ }^{1}$ Despite lacking formal authority, for practical purposes, the NAIC, is effectively in charge of the technical regulatory work, such as developing and implementing the risk based capital system.

${ }^{2}$ Data from 2012.

3 See Benmelech and Dlugosz (2011), Gordy and Willeman (2012) and Griffin, Nickerson, and Tang (2013) for some of the problems with structured securities and their credit ratings.
} 
Harris, 2013), were set to increase substantially under the existing rules. ${ }^{4}$ In this context, the NAIC decided to revise its rules. The stated aims were (i) to avoid using ratings in the wake of their poor performance for mortgage-backed securities issued before the financial crisis, and (ii) to reduce capital requirements for positions carried on insurance companies' books at below par. The reform had two main components, both of which are important to understand the impact on the capital requirements imposed on insurers and their investment behavior.

The first key feature of the reform was to replace credit ratings with regulator-paid "expected loss" assessments in capital requirement calculations for MBS. Thus, the reform allows us to study the first relevant attempt to reduce reliance on ratings in capital regulation of the financial sector, a key concern about existing regulation. ${ }^{5}$ For each MBS tranche, Pimco (for RMBS, starting year-end 2009) and BlackRock (for CMBS, starting year-end 2010) provide an estimate of the present value of expected principal losses ("ELOSS"). This continuous measure ranges between zero and one (compared to letter-grade ratings) and defines the intrinsic value (IV) of a security for regulatory purposes as 1 - ELOSS. We show theoretically and empirically that the intrinsic value IV can be understood as a proxy of the prevailing market price, i.e., if a bond trades at 70 cents on the dollar, the ELOSS measure is close to, but usually less than, 0.3 and the intrinsic value is correspondingly slightly above 0.7 .

The second key feature of the reform was to make the capital requirements for an asset depend on the book value at which it is held, and not exclusively on security-specific risk measures. Thus, the capital requirement becomes insurer-specific. Simplifying only slightly, the new regulation can be explained in a very simple way: an insurer's capital requirement for a security equals the difference between the book value of the security and its intrinsic value (IV), as determined by Pimco and BlackRock. Since intrinsic values are similar to the market values, any position that is marked to market requires (approximately) zero capital under the new system. This is true, for example, for two assets with different exposures to aggregate risks, but similar current market values, despite their different contribution to the probability of large losses, of distress, and of failure.

Concerns with the new rules were raised immediately, in particular since the new rules only apply to non-agency MBS, but not to corporate bonds, thereby favoring the holdings of risky structured securities: "They take one class of securities and change the rules [to give] insurers capital relief. Let's just hope they aren't picking something out that results in inadequate capital" (Wall Street Journal 2010). Indeed, the new system generated a large decrease in aggregate capital requirements for insurers. Insurers' capital requirements, called risk-based capital charges (RBC), for RMBS holdings at year-end 2009 were reduced by $67 \%$ compared to what they would have been had the ratings-based system been maintained. This translates into equity

\footnotetext{
${ }^{4}$ Koijen and Yogo (2012); Ellul, Jotikasthira, Lundblad and Wang (2013); as well as Merrill, Nadauld, Stulz and Shane (2013) show evidence that insurers were capital constrained during the crisis. Several insurance companies received federal support under the TARP program in late 2008.

${ }^{5}$ See, e.g., Opp, Opp and Harris (2013) and the Dodd-Frank Wall Street Reform and Consumer Protection Act (2010).
} 
capital savings of $\$ 7.6 \mathrm{bn} .{ }^{6}$ The gap between the two systems has been steadily increasing over time, as capital requirements under the new system remained flat but credit ratings of MBS continued to fall in line with continued losses and defaults. By 2012, total capital requirements for RMBS and CMBS were $\$ 3.73 \mathrm{bn}$ compared to hypothetical ratings-based charges of $\$ 19.36 \mathrm{bn}$, implying an RBC reduction of $\$ 15.63 \mathrm{bn}$. Around $90 \%$ of this reduction reflects non-agency RMBS. Two companies alone, Met Life and Teachers Insurance and Annuity Association, jointly saved $\$ 3$ bn in capital requirements.

We examine both aspects of the new rules: first, the new risk measure replacing credit ratings, and, second, the new system. We then consider the impact of the new rules on insurers' investment behavior.

The ELOSS measure is highly correlated with market prices (-0.85 for ELOSS produced by Pimco and -0.8 for BlackRock). In cross-sectional regressions predicting default, ELOSS contains some information that is neither contained in credit ratings nor in market prices. However, ELOSS does not outperform credit ratings outperform in predicting future defaults. Thus, our analysis rejects the idea that the new system uses more accurate inputs to regulation by replacing ratings. We also test whether Pimco and BlackRock exploit their new quasi-regulatory powers for their own trading purposes. We cannot find any evidence of this.

What about the new system for calculating capital requirements for MBS holdings? To evaluate the new system, we can rely on NAIC's stated rationale for capital requirements: "Risk based capital requirements limit the amount of risk a company can take. It requires a company with a higher amount of risk to hold a higher amount of capital. Capital provides a cushion to a company against insolvency."

With regards to this stated objective, our results are unambiguous: Compared to the previous system, not only does the new system require much lower levels of capital, but across firms and assets, capital has also become less related to the economic risk of asset positions. The mechanics of the new system can be illustrated with the following stylized example, assuming risk-neutrality and zero discounting for simplicity: consider an asset with $\$ 100$ par value and a $5 \%$ probability of paying off nothing, worth $\$ 95$ or a $\$ 5$ expected loss. Under the current system, this asset would be assigned a $\$ 5$ capital requirement if held at par (\$100), but (virtually) no capital requirement if held at $\$ 95$ (since book value equals asset value). The implicit hypothesis of the regulator is to treat the asset as if it had a certain $\$ 95$ payoff, and the new system requires no buffer against a payoff below that expected value. However, the asset is risky even if held at $\$ 95$ (with $5 \%$ probability its return is $-100 \%$ ), and if capital requirements should track risk, the asset deserves a non-zero capital requirement.

\footnotetext{
${ }^{6}$ This number is an approximation, disregarding various details of regulation, in particular covariance adjustments (see Section 1.1). We chose these numbers in particular to make them comparable to the official numbers posted by the NAIC (see Karapiperis, 2012). Insurers need to hold twice as much capital as the $\mathrm{RBC}$ requirement to avoid regulatory intervention (see Appendix A2).
} 
As is clear from this simplified description of the new system, it essentially only accounts for expected losses, i.e., losses that are already reflected in the market price but not yet recognized in the books of an insurer. Such a system only provides sufficient capital under the assumption that insurers hold a large number of independent asset risks, so that the aggregate portfolio is risk-free. While the law of large numbers is the foundation of insurance companies' liability side, it does not apply to asset markets, in particular structured securities, which are heavily exposed to aggregate shocks (see Coval et al., 2009). Thus, instead of requiring more capital for highsystematic risk assets, as Iannotta and Pennachi (2012) advocate, the new system implements the opposite.

We next document the effect of the new rules on portfolio choices, which allows us to study risktaking on the regulated entities. Generally, trading volume in outstanding MBS securities is low. Most tranches are hard to buy or sell, have wide bid-ask spreads, and are difficult to price. Despite the costs of trading in secondary markets, we document statistically significant flows toward favorably treated securities after the new system's implementation. ${ }^{7}$ Selective trading behavior within MBS is driven by two channels: 1) gains trading and 2) risk-based capital requirements. The gains trading channel predicts that insurers prefer to sell MBS assets with high market prices (relative to their book value) whereas the channel of risk based capital requirements (under the new system) suggests that insurers favor not selling assets with a high intrinsic value (relative to the book value). Thus, while the prediction with respect to an insurer's book value is theoretically ambiguous due to the conflicting channels of gains trading and capital requirements, the channels jointly imply higher selling incentives for securities with high market prices relative to their intrinsic value. Exploiting cross-sectional variation in the difference between the market price of the security and Pimco's / BlackRock's estimate of the intrinsic value we find strong evidence that insurers accumulate assets with low market prices and high intrinsic values in the RMBS market. In other words, within the MBS asset class, the new rules favored a risky portfolio composition with high-yield assets.

The effect on secondary markets is dwarfed, however, by the impact of the new system on insurers' purchases of newly issued securities. The new rules generated a substantial shift in how insurers invest in newly issued CMBS (non-agency RMBS issuance remains very low after the crisis). In the two years leading up to the new rules, purchases of newly issued CMBS by insurance companies were $92.5 \%$ investment grade (value weighted), but in the two years following the shift, investment was only $47.0 \%$ in investment grade assets. For comparison, corporate bond purchases, which were unaffected by the regulatory change, were $91.3 \%$ investment grade before the change, and $89.1 \%$ after. We interpret this as a strong distortion in insurance risk preferences driven by capital requirements. In a regression framework, we show that these results are not just driven by a change in the supply of CMBS assets between 2010

\footnotetext{
${ }^{7}$ This finding is corroborated by Hanley and Nikolova (2013) who show that insurers used the new rules to avoid selling underwater MBS positions. This evidence that regulatory capital drives insurers' portfolios of MBS is also in line with findings that insurance companies' holdings of corporate bonds respond to capital requirements (Ellul et al., 2011, and Becker and Ivashina, 2012). On the banking side, Behn, Haselmann, and Vig (2014) find evidence that German banks exploited the Basel II reform of capital requirements to grant risker loans via reporting systematically overoptimistic assessments of credit risk.
} 
and 2011, as the data show insurers replacing other investors (such as mutual funds) as purchasers of newly issued high yield CMBS. This historically unusual behavior by insurance companies has also been noted by market participants (see Morgan Stanley, 2014).

The trading patterns we observe are strongest among insurers with smaller capital cushions, both for trading in primary markets as well as in secondary markets. Our findings are thus consistent with risk-taking being the underlying motivation. ${ }^{8}$

Taken together, the regulatory reform produced a very large rebate on capital requirements, and appears to have distorted investment toward low quality MBS assets. These features suggest that the new system may sow the seeds for future solvency problems for insurers, in particular since the NAIC considers extending the new system to other asset classes.

Which regulatory rationale is consistent with these outcomes? One hypothesis is that the insurance industry actively influenced for the reform (Olson 1965, Stigler 1971, Peltzman 1976). This fits prior experience: Krozsner and Strahan (1999) argue that industry interests were important to U.S. financial regulation in 1970s and 1980s. Indeed, the new system of capital requirements for MBS achieved massive relief for the industry at a time when it faced very large losses and was struggling to meet regulatory requirements. Regulation may also have been driven by industry views absent capture in the traditional sense. Lawmakers and regulators are often forced to rely on the technical expertise of financial firms themselves: U.S. regulators have met with financial institutions more than 1,000 times to consult about the new Dodd-Frank rules. ${ }^{9}$ Direct input into the regulatory process provides an avenue of influence for regulated firms (Zingales 2013). Additionally, when more of the scrutiny of new rules is coming from industry, innocent regulatory mistakes that are against the industry's interests are more likely to be spotted, while mistakes serving industry interests will not be exposed. Such a process may bias the regulatory outcome and distort the effort of regulators (Leaver 2009).

Second, the new rules may have reflected a regulatory desire to avoid insurance companies failing and being taken over by states. The NAIC possesses no mechanism for regulatory forbearance on a firm-by-firm basis (although the TARP program run by the Federal Reserve did include several insurance companies, who likely avoided failure through the TARP equity injections). In practice, the only way for insurance regulators to avoid large numbers of defaults and state takeovers of life insurers may have been to reduce capital requirements. Under this hypothesis, regulatory behavior can be understood as a sort of macro-prudential regulation "on the fly", aiming to avoid macro-economic distress, and, in particular, to avoid the negative effects in insurance markets of insurance company failures.

\footnotetext{
${ }^{8}$ This result is in line with the theoretical prediction by Boyson, Fahlenbrach, and Stulz (2014) who study banks' incentives to engage in regulatory capital arbitrage as a function of overall capital constraints. Their empirical analysis supports this view by providing evidence that the extent of exploitation of a loophole is a predictor of riskiness, as measured by the degree to which an institution is affected by the financial crisis.

${ }^{9}$ Information from CNBC (2013) and USA Today (2013).
} 
Third, regulators may have perceived MBS as underpriced relative to other asset classes, perhaps reflecting a fire sale ${ }^{10}$ (see Shleifer and Vishny, 1992) or some other market failure, and did not want the industry to realize losses by selling at prevailing market prices. Implicit in this view is the assumption that regulators possess the ability to reliably spot asset classes with temporarily high expected returns, i.e., alpha. While the MBS market indeed recovered strongly since the crisis, it is unclear to which extent one should attribute the realization, in line with the "predicted" price increase, to luck or skill. A more subtle version of this argument is that the capital relief for MBS allowed the industry to avoid the firesale that would have occurred in the absence of regulatory reform. We note that this argument, however, does neither imply an expected price recovery of MBS (since the insurer-driven firesale was avoided) nor does it imply that the capital relief should also be granted for new purchases of MBS.

According to the second and third view, there are benefits of the capital relief. However, in both cases the regulator's desire should be to lower capital requirements temporarily, not permanently. With a permanent change, the benefits of capital relief have to be weighed against the (long-run) cost of increased systemic risk as a result of risk-taking. As discussed above, the incentive to take on more risk within MBS appears to be reflected in portfolio choices since the new system was introduced.

The change in the capital regulation for U.S. insurers offers insights that are relevant outside the US insurance industry, especially for regulating the banking industry. The new model, based on measures of credit risk for which the regulator pays (instead of using credit ratings for which the issuer pays), may offer a method for replacing ratings in financial regulation elsewhere. The insurance industry's experience provides a laboratory for assessing the costs and benefits of one particular alternative to rating-contingent regulation. The new input measure "ELOSS" provided by Pimco and BlackRock is useful, but not better than ratings. The crucial regulatory change thus appears to occur at the level of system design rather than the input.

Our study complements research on the interconnection between regulation and insurance company decisions during the financial crisis. This literature shows how an existing set of regulatory rules affects the behavior of constrained insurance companies, including product market decisions (Koijen and Yogo, 2012, provide evidence on underpricing of life annuities) or portfolio decisions (Ellul, Jotikasthira, Lundblad 2011, and Ellul et al., 2013) when subjected to financial stress. Finally, the issue of design of new rules is also related to their enforcement, studied in the bank context by Agarwal, Lucca, Seru and Trebbi (2012).

Our paper is structured as follows. In Section 1, we lay out an overview of the regulatory framework and the underlying changes. Section 2 describes the data sources. Section 3 presents our empirical results with regards to the effect of this system on capital requirements. In Section 4, we analyze the repercussions on the insurance companies' risk taking behavior. Section 5 analyzes the new input "ELOSS" and compares it to ratings. Section 6 concludes.

\footnotetext{
${ }^{10}$ Insurers are large holders of both CMBS and non-agency RMBS (about twice the holdings of depository institutions). Their potential impact on these markets may therefore be large.
} 


\section{Capital requirements for U.S. insurers}

Like banks, U.S. insurance companies have many liabilities with public guarantees, and are subject to capital requirements aiming to protect policyholders and taxpayers from excessive risk. While our study is concerned with the change in how capital requirements are determined for structured securities, we provide a concise overview of the overall system for capital regulation in Section 1.1. We abstract from some technical details. The regulatory change we examine and its motivation are described in Section 1.2. In Section 1.3., we discuss the empirical predictions which we examine in the subsequent empirical analysis.

\subsection{Overall Capital Requirements}

Since 1994, the NAIC uses a risk-based capital system to regulate insurance companies, similar to the Basel guidelines for bank capital requirements. ${ }^{11}$ For all insurer types (Life, Property \& Casualty (P\&C) and Health Insurers) appropriate capitalization is measured by the RBC ratio, which relates a measure of book equity (total adjusted surplus), to a measure of total risk, technically labeled the risk-based capital requirement:

$$
\mathrm{RBC} \text { ratio }=\frac{\text { Equity }}{\text { Risk-Based Capital Requirement }}
$$

The RBC ratio is computed for all insurance companies at an annual level. When equity falls short of two times risk-based capital, i.e., $\mathrm{RBC}$ ratio $\leq 2$, the regulator has the right to intervene in the business of the insurer. ${ }^{12}$ Our study is primarily concerned about the determination of risk-based capital requirements, which can be expressed as:

$$
\text { Risk-Based Capital Requirement }=R_{0}+\sqrt{\sum_{i=1}^{5} R_{i}^{2}}
$$

Here, $R_{i}$ represents risk charges for risk source $i$, including asset risks, underwriting risks and business risks. For example, for a $\mathrm{P} \& \mathrm{C}$ insurer, $R_{0}$ to $R_{2}$ represent asset risks (from affiliate companies, fixed income, and equities, respectively) whereas categories $R_{3}$ to $R_{5}$ account for credit risk, reserving risk and premium risk (see Appendix A.1). The (square-root) formula suggests that the risk-based capital requirement can be roughly related to volatility, and assumes that the risk components 1 to 5 have zero correlation. ${ }^{13}$

To get a sense of the safety buffer implicit in this regulation, it is useful to consider a hypothetical example of an insurer that only faces asset risks in the form of a stock portfolio (essentially acting as a mutual fund). The current regulation sets the capital requirement for stocks to $15 \%$ of the book-value, i.e.; a $\$ 10 \mathrm{bn}$ stock portfolio would require a risk based capital

\footnotetext{
${ }^{11}$ Prior to the introduction of the RBC system, capital requirements for insurers were fixed, and depended only on the line of business and the state in which a firm operated. The range was $\$ 500,000$ to $\$ 6,000,000$. 12 The harshest form of intervention is mandated if the RBC ratio drops below 0.7. Then, the insurer is placed directly under regulatory control, (see Appendix A.2. for the hierarchy of regulatory interventions).

${ }^{13}$ The term $\mathrm{R}_{0}$ is outside of the square root to prohibit regulatory arbitrage via the legal structure of companies. Koijen and Yogo (2013) show that captive reinsurers can be used to sidestep this.
} 
requirement of $\$ 1.5 \mathrm{bn}$, translating into a $\$ 3 \mathrm{bn}$ minimum equity requirement to avoid regulatory interventions. Thus, the risk buffer $(2 \mathrm{xRBC})$ is set to roughly twice the annual stock market volatility of $15 \%$ (see Campbell et al., 2001).

\subsection{Fixed-Income Capital Requirements Reform}

The regulatory experiment that we analyze concerns RBC charges for structured securities, a subcategory of fixed income $\left(R_{1}\right.$ above). The risk-based charge (RBC) for non-treasury fixed income securities is a product of their book value $(\mathrm{BV})$ and a percentage risk-based capital charge $(\mathrm{RBC} \%)$ based on the NAIC risk classification (1-6), as illustrated by Table 1. Here, NAIC category 1 refers to the lowest risk class and NAIC 6 represents the highest risk category. ${ }^{14}$ For example, a NAIC 4 bond with a book value of $\$ 100$ would command a $\$ 10$ RBC charge if held by a life-insurance company. The RBC charge for the entire fixed income portfolio of an insurer with $\mathrm{N}$ bonds is then given by:

$$
R_{1}=\sum_{j=1}^{N} \mathrm{RBC}_{j}=\sum_{j=1}^{N} \mathrm{BV}_{j} \mathrm{RBC}_{j}
$$

Prior to year-end 2009, the NAIC risk classifications were exclusively determined by ratings of acceptable ratings organizations (AROs) as illustrated in the fourth column of Table $1 .{ }^{15}$ That is, a AA-rated bond received a NAIC1 designation whereas a B-rated bond was considered NAIC4. ${ }^{16}$ While corporate bond risk classifications still follow this ratings-based classification scheme, the NAIC started using a new system for non-agency backed RMBS and CMBS.

Following unprecedented downgrades of structured securities by rating agencies in 2008/2009, the NAIC decided to make fundamental changes in how to classify the risk of RMBS securities: In the fall of 2009, the NAIC solicited bids for the business of assessing the risk of roughly 18,000 RMBS requiring that the bidders have five years of experience, have safeguards against conflicts of interest, and be financially sound. ${ }^{17}$ Pimco was eventually selected for 2009 capital requirements or RMBS and has performed this function since. In a similar process, BlackRock was selected to assess risks for CMBS in 2010. BlackRock and Pimco provide measures of risk called "expected losses."

\footnotetext{
${ }^{14}$ Holdings of US treasuries are not subject to a risk-based charge. The risk-based charges for life insurance companies differ from the risk-based charges of P\&C insurers, as columns 2 and 3 in Table 1 illustrate.

${ }^{15}$ In March 2013, AROs were Moody's, Standard and Poor's, Fitch, DBRS, A.M. Best, RealPoint, and Kroll Bond Rating Agency, largely the same set of CRAs as those designated nationally recognized statistical ratings organizations (NRSROs) by the SEC.

${ }^{16}$ When two ratings are available, the lower one is used. When three or more ratings are available, the second lowest is used.

${ }_{17}$ There were bids from twenty vendors, of which eleven were short-listed and subject to analysis by NAIC and a financial consultant. This set was narrowed to four, which were assessed based on their valuation of individual securities.
} 
New Input to Regulation: For each security, they first estimate losses of principal payments in 5 different macro scenarios for the U.S. economy and real estate prices. ${ }^{18}$ These statecontingent losses are then mapped into a single expected loss variable by discounting losses with the coupon yield of the asset and weighing them with the probability of the respective scenario. ${ }^{19}$ The regulator only uses state contingent losses through this summary statistic, ELOSS $\in[0,1]$, which defines the "intrinsic value" (IV) of a security:

$$
\text { IV }=1-\text { ELOSS }
$$

Thus, the intrinsic value of a bond with $30 \%$ expected loss is given by $70 \%$ of par. To interpret this "intrinsic value," it is useful to foreshadow an important empirical result. The intrinsic value provided by Pimco and Blackrock is highly correlated with the market price of a bond with coefficients of 0.85 and 0.80 , respectively, and is typically above the market price as indicated by the fitted polynomial relative to the 45 degree line in Figure 1.

New System Intuition: The new regulation defines the "risk" of a security $j$ in the portfolio of insurer $i$ as the difference between the accounting book value of the insurer $\left(\mathrm{BV}_{i, j}\right)$ and the intrinsic value $\left(\mathrm{IV}_{j}\right)$ :

$$
\mathrm{RBC}_{i, j}=\mathrm{BV}_{i, j} \mathrm{RBC}_{i, j} \approx \mathrm{BV}_{i, j}-\mathrm{IV}_{j}
$$

where we conveniently normalize the par value of any security to $\$ 1$. This approximation reveals that if an insurer records a security at $50 \%$ of par, an intrinsic value of 0.49 implies a 0.01 capital requirement for that bond or equivalently a $\mathrm{RBC} \%$ charge of $2 \%$ on the prevailing book value of 0.5 . It is immediate that this notion of "risk" only captures losses that are expected to occur rather than providing buffers against adverse scenarios (unexpected losses).

New System Actual: The actual regulation implements Eq. (4) in a discontinuous way: Instead of simply requiring $\left(\mathrm{BV}_{i, j}-\mathrm{IV}_{j}\right) / \mathrm{BV}_{i, j}$ as the $\mathrm{RBC} \%$ charge, the regulator reverse engineered 5 cutoffs depending on the value of (BV - IV) / BV (see columns 4 and 5 in Table 1) so that the new system still preserves the 6 NAIC risk categories of the old system. ${ }^{20}$ As a result, actual capital requirements are bounded below by the NAIC 1 risk charge, which is $0.4 \%$ for life insurers, and bounded above by 30\%, the NAIC 6 risk charge. Continuing our example

\footnotetext{
18 The base case scenario occurs with 50\%. There are also 2 more aggressive as well as 2 more conservative scenarios (with respectively, $2.5 \%$ and $22.5 \%$ probability). The NAIC has control over how to define the scenarios, which might also change from year to year. The number of scenarios has recently been reduced to four.

${ }^{19}$ We will discuss the potential bias resulting from the choice of discount rate in Section 1.3 and Appendix A3.

${ }^{20}$ To understand the magnitudes of the risk based charge, observe that the cutoffs (in Table 1) are simply the average of the respective adjacent NAIC RBC\% charges: For life insurers the NAIC1 cutoff is thus given by $(0.4 \%+1.3 \%) / 2=0.85 \%$. These cutoffs ensure that the approximation in Equation 4 holds. There is one exception to the just described mechanics of book-value adjustments: If a security has zero expected loss, then it belongs in the NAIC 1 category regardless of its book value.
} 
from above, a bond with an expected loss of $2 \%$ relative to the book value will fall into NAIC risk category 2 if held by a life insurer, i.e., commanding a $1.3 \% \mathrm{RBC} \%$ charge, and will fall into risk category 3 if held by a $\mathrm{P} \& \mathrm{C}$ insurer, i.e., commanding a $2 \% \mathrm{RBC} \%$ charge (See Table 1). For both types of insurers, actual capital requirements are close to the predicted $2 \%$. To gauge the accuracy of our approximation over the relevant range, we plot the actual $\mathrm{RBC} \%$ for life insurers charge as a function of $(\mathrm{BV}-\mathrm{IV}) / \mathrm{BV}$ in Figure 2. Graphically, the approximation of Eq. 4) is represented by the (red) 45-degree line whereas the actual system is given by the (black) step function. It is one of our contributions to convey the simple mechanism of the system, summarized by Eq. 4, based on the discontinuous structure of the official rules implied by the cutoffs (see Table 1).

The official rationale behind implementing this concept of risk was to avoid causing "double jeopardy" for insurers who were already forced by accounting rules to mark most of their bonds to market, affecting the numerator (equity) of the RBC ratio (see Eq. 1). ${ }^{21}$ High capital requirements (the denominator) would no longer be necessary.

\subsection{Discussion / Hypotheses}

As the description revealed, this type of capital regulation ensures risk buffers just enough to sustain average, i.e., expected, losses. While such a safety cushion is perfectly sound for a welldiversified portfolio of independent risks - due to the law of large numbers - it will not provide protection against aggregate losses in the asset portfolio, such as due to exposure to systematic risks. Since insurers typically hold large, diversified asset portfolios, systematic risk ought to be a key consideration for designing regulatory capital buffers (regardless of whether capital requirements aim to protect tax payers from losses in guaranteed firms, or to incentivize limited risk taking, or both).

It is easiest to show the implications of the "old" and "new" system using a stylized example with two zero-coupon bonds $\{S, I\}$, two equi-probable macro-states, and zero discounting. Bond $S$ pays off fully in the good macro state and does not pay out anything in the bad state. In contrast, bond $I$ will pay off $50 \%$ of par in both macro-states. By design, the bonds have very different exposures to systematic risk: Only bond $S$ is risky whereas bond $I$ is risk-free. However, since both bonds have high expected losses, both bonds contain significant credit risk, which will be reflected in ratings (non-investment-grade) and ELOSS (50\%). Thus, according to the input dimension, the previous and current systems are very similar in that both rely on credit risk metrics rather than metrics of systematic risk. ${ }^{22}$ Thus, one key criticism of using credit ratings

\footnotetext{
${ }^{21}$ The accounting treatment of a structured bond depends itself on the intrinsic value. If the amortized cost (AC) of a bond is sufficiently above the intrinsic value (IV), then the bond has to be marked to market and can no longer be held at AC. The cutoffs for marking-to-market differ across life and P\&C insurers. For life insurers, the cutoff is the NAIC 5-6 threshold, i.e., if IV is $26.5 \%$ below AC. For P\&C insurers, the cutoff is the NAIC 2-3 threshold, i.e., if IV is $1.5 \%$ below AC. Once a bond is marked to market, so that $\mathrm{BV}=\mathrm{MV}$, the capital charge becomes typically NAIC 1, since the market price is below IV for most bonds (see Figure 1).

${ }^{22}$ In general, there is a positive correlation between measures of credit risk, such as ratings, and measures such of systematic risk (beta), see e.g. Hilscher and Wilson (2013). However, this relationship differs across asset classes.
} 
for capital regulation, namely the lack of distinction between systematic and unsystematic risks (Iannotta and Pennacchi, 2012), has not been addressed.

To understand the difference between the old and new systems, suppose that both bonds are purchased in the secondary market at $50 \%$ of par, and that the book value is also $50 \%$ of par. Under the old system, the high credit risk of both bonds (non-investment grade ratings) directly translate into the highest NAIC risk classification 6, implying a 30\% capital charge (see Table 1 ). Under the new system, however, the high ELOSS (IV=50\%) of both bonds does not directly translate into high capital requirements, since the expected credit risk loss is first netted against the loss recognized in the book value (see equation 4). Since IV $=$ BV, both bonds would now be assigned the NAIC1 category with $0.4 \%$ capital requirements. This "netting" feature implies that the new system only provides sufficient capital buffers to cover losses in bad states for type $I$ bonds, i.e., bonds with low systematic risk.

The new system only applies to structured securities which are, by design, heavily exposed to systematic risk (Coval et al., 2009), much more than corporate bonds with similar expected loss. If anything, a regulatory reform aimed at providing sufficient risk buffers equally across security classes should command higher risk charges for structured securities than for corporate bonds, holding expected loss constant.

Implication 1: The new system of capital requirements for structured securities does not account for unexpected losses and hence provides insufficient capital cushions against adverse aggregate movements.

While the system is not designed to protect against adverse systematic shocks, a sufficiently conservative input, in this case the intrinsic value, would effectively imply additional risk buffers. For example, if a bond's market price (and for simplicity its book value) is 0.5 an intrinsic value of 0.4 would imply a substantial economic capital requirement of (approximately) 0.1, i.e., a cushion against a $20 \%$ loss from the prevailing market price.

It is therefore important to understand the relation of the market price (MP) and IV. In general, the market price of a bond should equal the present value (PV) of (expected) principal and coupon payments. In turn, the portion of the value associated with principal repayments can be expressed as the difference of a risk-free zero coupon bond (with associated market price $1-R_{F}$ ) and the expected discounted loss of principal, ELOSS $\mathrm{M}_{\mathrm{M}}$. Note that $R_{F}$ can be interpreted as the (total) interest over the lifetime the bond. In contrast to ELOSS, the "true" market value of losses, ELOSS $\mathrm{M}$, is computed by discounting losses in each state of the world with the appropriate stochastic discount rate (see Appendix A3.) rather than the coupon rate.

$$
\mathrm{MP}=\underbrace{1-R_{F}-\mathrm{ELOSS}_{\mathrm{M}}}_{\mathrm{PV}(\text { Principal })}+\mathrm{PV}(\text { Coupons })
$$

Now using the definition of IV $=1$ - ELOSS we obtain the following decomposition of IV

$$
\mathrm{IV}=\mathrm{MP}+\left(\mathrm{ELOSS}_{\mathrm{M}}-\mathrm{ELOSS}\right)+R_{F}-\mathrm{PV}(\text { Coupons })
$$


The decomposition makes it obvious that bonds with high coupon payments have lower IV and thus be at a regulatory disadvantage. Moreover, a higher market assessment of discounted losses, ELOSS $\mathrm{M}$, relative to the estimate by Pimco/BlackRock, leads to higher IV. Basic finance theory suggests that there is indeed a systematic difference between ELOSS $_{M}$ and ELOSS. The present value calculation of ELOSS performed by Pimco/BlackRock uses the coupon rate as the discount rate. In contrast, the market assessment, ELOSS ${ }_{\mathrm{M}}$, should depend on state-contingent prices: Since losses tend to occur in bad aggregate states of the world with high marginal utility, the market expectation of losses must be greater than the losses using a state-independent discount rate equal to the coupon rate. We provide a formal derivation of this argument in Appendix A.3. ${ }^{23}$

Implication 2: Because the discount rate of ELOSS does not appropriately reflect the risk of

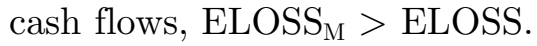

Additionally, coupons are typically modest on structured securities (riskier tranches are often issued below par, instead of with higher coupons, to avoid large cash flows to these tranches before senior claims have been paid), thus, $\mathrm{PV}$ (Coupons) is likely of similar magnitude as $R_{F}$. Implication 2 then suggests that we can expect IV to be low compared to MP. Finally, since many structured securities are marked to market, i.e., $\mathrm{BV}=\mathrm{MP}$, capital requirements in the new system are expected to be low as a result (see Equation 4):

Prediction 1: The new system implies (large) savings in aggregate capital requirements relative to the old ratings-based system.

The new capital regulation not only reduces overall levels of capital, but also introduces distortions across asset classes. Recall that corporate bonds, despite their lower systematic risk (see Coval et al., 2009), are still subject to the relatively more stringent ratings-based capital regulation. If insurers want to reach for yield (Becker and Ivashina, 2012) they can now purchase the riskiest tranches of structured securities at (essentially) zero regulatory cost.

Prediction 2: The new system will increase the insurers' willingness to bear risk in structured securities (but will not change the risk appetite for asset classes whose capital requirements were not affected, including corporate bonds).

Finally, relying on large institutional investors to provide risk assessments rather than issuerpaid credit rating agencies might introduce (new) conflicts of interests. Pimco and BlackRock, the largest bond investors, have the opportunity to influence the capital requirements of their likely counterparties in the asset market and the regulatory constraints of the clients of their asset management business.

Prediction 3: Pimco and BlackRock have an incentive to rate assets they hold favorably. This is especially true for those they intend to sell.

${ }^{23}$ Almeida and Philippon (2007) make a similar point in the context of estimating distress cost. 


\section{Data}

We use data from a variety of sources. We obtain two distinct data sets from the NAIC: The first data set provides us with the ELOSS measure at the CUSIP level for the universe of nonagency RMBS in 2009 and 2010, and for the universe of CMBS in 2010 and 2011. There are 23,765 cusips of RMBS in 2009 and 21,575 in 2010. There are 5,293 cusips of CMBS in 2010 and 5,974 in 2011. This includes all securities for which there are positive holdings in the U.S. insurance industry (in any year) as well as a few additional securities (where an insurer may have requested an $\mathrm{RBC}$ number).

A second data set from the NAIC provides us with CUSIP-level holdings information for all insurance companies in the US (Schedule D Part 1) from 2007-2012. This data set covers end-ofyear holdings for all fixed income securities (including treasury bonds, corporate bonds, agency backed RMBS) providing us with insurer-specific book-adjusted carrying values, par values, market values and NAIC risk classification in addition to insurer characteristics (such as the state, business type: Life, P\&C, Health, Fraternity and Title). We use book values of each insurer to calculate holding-level RBC requirements (according to Table 1) and then aggregate these at the insurer, business type and industry level. When calculating capital requirements for the total fixed income portfolio, we take into account that treasuries are exempt from a capital charge. ${ }^{24}$ This data also allows us to construct a yearly time series of market prices for each security. We note that the "market prices" used in this paper are based on insurance firms' reporting, typically of year-end broker quotes. ${ }^{25}$ That is, these prices are not necessarily tradable quotes, but the best proxy available given the low liquidity of many securities.

Table 2 provides detailed summary statistics of the holdings data. In the time period between 2009 and 2012, aggregate holdings of all insurer types in fixed income grew from $\$ 3.3$ trillion to $\$ 3.6$ trillion with the predominant share of these assets held by life insurers (70\%) and P\&C insurers $(27 \%)$. During the same time period, capital requirements for the entire portfolio fell from $\$ 50 \mathrm{bn}$ to $\$ 37 \mathrm{bn}$, translating into an average $\mathrm{RBC} \%$ charge of $1.5 \%$ (1\%) of the book values. We will revisit the two sub-categories RMBS and CMBS in the next section. The 2009 to 2012 period is characterized by falling book values of MBS held by the insurance industry. Lower book valuations are a small part of this. ${ }^{26}$ Instead, the drop reflects matured securities, sales of assets, and a lack of new issuance (CMBS issuance revived somewhat in 2011 and 2012, but non-agency RMBS remains very low).$^{27}$

\footnotetext{
${ }^{24}$ Treasuries in our sample are recorded as all CUSIPs whose first 5 digits are between 91274 and 91283.

25 The most common sources for quotes are: Barclay's, Blackrock, Bloomberg, Interactive Data Corporation, Lehman, and Reuters. Since different insurers may use different sources for a given security, we average the market price across sources. The differences are typically negligible, which may be explained by the fact that the different companies rely on the same valuation tools (such as Intex).

${ }^{26}$ From 2009 to 2012 , the book value of RMBS held fell by $\$ 42$ billion (from $\$ 150$ to $\$ 108$ billion), and par value held fell by $\$ 43$ billion (from $\$ 178$ to $\$ 135$ billion).

${ }^{27}$ U.S. CMBS issuance fell from $\$ 229$ billion in 2007 to $\$ 3$ billion in 2009, recovered to $\$ 48$ billion in 2012 and exceeded $\$ 85$ billion in 2013 .
} 
We additionally collect quarterly holdings data from eMAXX of US institutional investors, in particular mutual funds, insurance companies and pension funds. For non-insurance investors, only the par amount is reported. ${ }^{28}$ The data ends in 2012. The eMAXX data indicates both the owner and the manager for most holdings, i.e., when an insurance company delegates management, the identity of the external manager is usually observed. The main use of eMAXX data is to determine the holdings for Pimco and BlackRock as we obtain insurance company holdings directly from the NAIC.

In order to compute counterfactual capital requirements under the previous ratings-based system (according to Table 1) we collect data on credit ratings directly from the two largest CRAs, S\&P and Moody's. We complement these with Fitch ratings from eMAXX. The ratings data sets contain information about individual assets such as maturity, issue date, seniority etc. Of our RMBS 2009 universe, $6.8 \%$ of securities are unrated, $22.7 \%$ have one rating, $65.2 \%$ have two ratings, and 5.4\% have three ratings. S\&P, Moody's and Fitch covered $79 \%, 64 \%$ and $27 \%$ of securities by number and $82 \%, 89 \%$ and $27 \%$ by value, respectively.

Overall, our sample period saw a steep decline in the ratings of MBS securities. For RMBS securities, the median S\&P (Moody's) rating was AAA (AAA) in 2008, A (BBB-) in 2009, BB+ $(\mathrm{B}+)$ in 2010, B- $(\mathrm{CCC}+)$ in 2011 and $\mathrm{CCC}(\mathrm{CCC})$ in 2012 (this includes defaulted securities). CMBS experienced a smaller decline: the median Moody's rating was AA in 2008, AA in 2009, $\mathrm{A}+$ in 2010, A in 2011, and BBB in 2012.

We additionally use credit ratings to estimate defaults of securities subsequent to the RBC calculation. We define a security as defaulted if it was downgraded to CCC or below, or, if the rating disappears after reaching BB- or lower (Griffin, Nickerson, and Tang 2013 regarding some of the issues in identifying defaults and an alternative method). This method relies on credit ratings. As an alternative measure of performance of MBS securities, independent of credit ratings, we use losses up to year end 2012, from Qian, He and Strahan (2013). This data is available for approximately $70 \%$ of MBS securities held by insurers (these securities represent $80 \%$ of total par value). Table 3 summarizes insurance holdings and various credit metrics for each CUSIP in the first year of the new system for capital requirements (2009 for RMBS and 2010 for CMBS). ${ }^{29}$

\section{Aggregate Capital Requirements}

We first examine how aggregate capital requirements changed as a result of the system change. We compare actual capital requirements based on ELOSS to those that would have obtained had the rating-based system been maintained (using actual year-end ratings).

\footnotetext{
${ }^{28}$ When coverage of eMAXX and NAIC holdings overlap (year-end insurance holdings), there are some discrepancies where eMAXX report lower values. Based on a investigating a few situations in detail, we consider the NAIC data more useful on these occasions.

${ }^{29}$ All columns in Table 3 are based on all available securities. Aggregate insurance holdings of RMBS in 2009 add up to $\$ 147$ billion, which is lower than the total in Table 2 ( $\$ 150$ billion) because some assets lack ratings.
} 
Since ELOSS and its transformation to intrinsic value (see Eq. 2) represents a key input variable for individual and aggregate capital requirements (via Eq. 3 and 4), it is important to understand its first-order determinants. Our empirical analysis shows that the market price of a security alone goes a long way of explaining ELOSS. The correlation coefficients for ELOSS provided by Pimco and BlackRock are -0.85 and -0.80 , respectively. While the (high) correlation of ELOSS implies that ELOSS picks up cross-sectional variation in market prices, it does not tell us whether the level of the "intrinsic value" tends to be above or below the market price. To this end, Figure 1 plots the intrinsic value provided by Pimco (left panel) and BlackRock (right panel) against year-end market price (broker quotes). Consistent with Implication 2, the fitted polynomial is above the 45 degree line. In short, the regulator-paid assessments by Pimco and Blackrock can, to a first-order approximation, be understood as upward-biased proxies of the market price, consistent with our discussion in Section 1.3. We also note that a significant fraction of securities is considered zero-loss, implying an intrinsic value of 1: This occurs for $42 \%$ of RMBS tranches and $67 \%$ of CMBS tranches. While these basic facts about ELOSS are sufficient for understanding the effect of the new input on capital requirements, we provide additional analysis of the new input measure, such as its ability to predict defaults in Section 5 .

The time-series of aggregate capital requirements measured as a fraction of (aggregate) book values are plotted in Figure $33^{30}$ For RMBS, the new system produced a sharp decrease in capital requirements compared to previous ratings-based system, as the left panel illustrates. With the transition to the new system in 2009, the industry-wide RBC requirement for RMBS (as a fraction of book values) rose by $40.7 \%$ compared to 2008 levels, ${ }^{31}$ instead of rising by $425.8 \%$ if the old system had been maintained. In other words, the introduction of the new system allowed the insurance industry to avoid the effects a massive increase in capital requirements that would otherwise have taken place, reducing the $\mathrm{RBC}$ requirement for nonagency RMBS by $67.0 \%$ (equivalent to a $\$ 7.6$ billion reduction of $\mathrm{RBC}$, see Table 2 ). The hypothetical increase in capital requirements under the old system reflects downgrades of many MBS securities, both in response to house price developments and to changes in methodologies. The effect of the new system was even more striking in 2010, the second year of the new system. 2010 capital requirements were $78.2 \%$ below the ratings-based counterfactual, reflecting both a reduction in capital requirements under the new model and considerable further deterioration in ratings, which would have raised $\mathrm{RBC}$ requirements under the old system. The discount of the new system compared to the old one was over 80\% in both 2011 and 2012. Despite the small and falling portfolio share invested in RMBS (4.5\% in 2009, 3.0\% in 2012), aggregate capital requirements of the fixed income portfolio are significantly affected by the change in RMBS capital requirements (see Table 2). In 2009, aggregate RBC savings for the entire fixed income portfolio were $13.2 \%$, then growing to $28.6 \%$ in 2012. This effect is driven by the high riskweights of RMBS compared to the remaining "low-risk" fixed-income assets. Under the old

\footnotetext{
${ }^{30}$ We only look at the direct effect on capital requirements, ignoring the covariance adjustment (see Section 1.1.) Moreover, to be conservative, we did not multiply our numbers with 2, which is the required $\mathrm{RBC}$ ratio to avoid any regulatory intervention (see Appendix A2).

${ }^{31}$ We obtain the 2008 capital requirements for RMBS from the NAIC rather than using our own calculations.
} 
regulation, the RMBS portfolio RBC charge would have been $\$ 17.23$ billion in 2012 , or $16 \%$ of book value, which is comparable to the $\mathrm{RBC} \%$ on equities $(15 \%)$.

We now turn to CMBS. The right panel of Figure 3 illustrates that capital requirements for the less risky CMBS are much lower to begin with under the previous regulation, limiting the absolute amount of savings a reform can achieve. In fact, in the first year of the new system, aggregate capital requirements for CMBS are virtually unaffected by the reform even on a relative scale: they were $0.4 \%$ lower than they would have been under the old RBC system. After the first year, however, the new system has become progressively more lenient relative to the old ratings-based system. The relief in the $\mathrm{RBC}$ requirement (as a faction of book values) relative to the hypothetical old system was $36.2 \%$ in 2011 and $44.3 \%$ in 2012.

Overall, the new system has produced a massive reduction in the capital insurers have to hold against MBS, relaxing their overall constraints significantly compared to what would have happened with the old system in place. Assessing the welfare consequences of this change is beyond the scope of this paper. However, the fact that capital requirements saw a sharp decline at a time of historically high default rates for this asset class suggests that the new regulation fails to provide protection against long term losses. Recent experience shows that MBS can be very risky assets at times: the equal (value) weighted, three year forward-looking default rate for the 2009 RMBS universe was around $39 \%$ (24\%).

To illustrate the differential treatment of risk under the new and old system, we plot the decomposition of RMBS holdings into the 6 NAIC risk categories on the horizontal axis and the associated 3-year default rates on the vertical axis, separately for the new system (Panel A) and the old system (Panel B). Default rates are determined according to the methodology determined by Griffin, Nickerson, and Tang (2013). Under the new system, default rates for the safest category (NAIC 1) exceed $10 \%$ for the new system, but were below $1 \%$ for securities rated AAA through A- (the range of ratings that previously defined the NAIC 1 category). This result is a direct implication of the definition of risk in Eq. 4. Securities only require capital if the book value is sufficiently above the intrinsic value. Since market prices are on average higher than intrinsic values (see Figure 1), bonds with a high NAIC risk classification are therefore predominantly bonds that insurers have not marked to market.

Qualitatively, the results for CMBS are similar, though the magnitudes are smaller since CMBS are simply less risky than RMBS. This finding is also in line with the fact that the bulk share of capital savings results from the change in capital regulation for RMBS (see Figure 3) rather than CMBS.

\section{Portfolio Allocations and Capital Requirements}

We now analyze the impact of the new capital requirements on insurers' asset holdings. Capital requirements' should force risky firms to hold sufficient capital, given a set of portfolio and operational risks, or, to the extent that regulatory capital has a positive shadow cost, affect investment decisions of regulated firms. We examine the impact of the new rules on investment 
decisions, first by examining trading of existing assets and then purchases of newly issued securities.

\subsection{Rebalancing portfolios}

The new capital requirements rules implied low capital requirements for most MBS securities. However, there is still considerable cross-sectional heterogeneity. We exploit this to examine whether trading of U.S. insurers' MBS holdings in the year following the implementation of the new rules was related to the new capital treatment. ${ }^{32}$ We aggregate all insurance holdings of a given security in a given year. Our source of variation, and the key input to capital requirements, is intrinsic value. Since intrinsic value is the same for all insurers, treating different insurers as separate units of observations risks inflating the number of observations and statistical significance. ${ }^{33}$ We compare holdings at the end of the first year of the new rules (2010 for RMBS and 2011 for CMBS) to holding of the same security a year before.

If insurers find regulatory capital costly (as the findings of Ellul, Jotikasthira, and Lundblad 2012, Koijen and Yogo, 2012, and Becker and Ivashina, 2012, suggest), we expect a divestment of assets with high capital requirements. Selective trading incentives due to capital requirements within MBS can be driven by two channels: 1) gains trading and 2) risk-based capital requirements. The gains trading channel predicts that insurers prefer to sell MBS assets with high market prices (relative to their book value) whereas the channel of risk based capital requirements suggests that insurers favor selling assets with low intrinsic value (relative to the book value). Thus, while the prediction with respect to an insurer's book value is theoretically ambiguous due to the conflicting channels of gains trading and capital requirements, the channels jointly imply higher selling incentives for securities with high market prices relative to their intrinsic value. Our cross-sectional analysis exploits variation in the difference between the market price and the intrinsic value across securities (see Figure 1).

In column (1) of Table 4, we report a regression for RMBS, with no controls. To simplify the analysis, we first focus on the difference between market price and intrinsic value (MP-IV). We report the mean of the dependent variable at the top of each column. In column (1), the mean is -0.21 , meaning that on average, there is a reduction in insurers' RMBS holdings in 2010. The coefficient on MP-IV in column (1) is large, negative and highly statistically significant. ${ }^{34}$ A $10 \%$ differential between market price and intrinsic value is associated with $2.3 \%$ drop in industry

\footnotetext{
${ }^{32}$ We use par values, and not book values, to make sure only actual trading affects our results. Changes in book values reflect trading, but may also vary due to accounting adjustments. For the same reasons, we exclude defaulted and matured assets (this restriction does not in practice impact our results qualitatively).

${ }^{33}$ The problem of exaggerating statistical power when unit of observation is more smaller than the level of variation of the variable of interest is discussed in the context of difference-in-difference estimates in Bertrand, Duflo, and Mullainathan (2004) and Donald and Lang (2007).

${ }^{34}$ Capital requirements are lower for property and casualty insurers, and the accounting rules differ. We have separated holdings into life insurance and non-life (i.e. health and other as well as property and casualty). The results in Table 4 hold for both, but are weaker and slightly less significant for non-life.
} 
holdings for an asset in the year after the new rules were implemented. In other words, insurers' trading moved their RMBS portfolios toward low market value, high intrinsic value assets. ${ }^{35}$

If the trading patterns documented in column (1) reflect insurers' attempts to economize on capital requirements (while taking risk in their RMBS portfolios), we expect the behavior to be more pronounced for those insurers who care more about capital requirements, for example because they find capital more expensive or are more eager to take risk (i.e., they are reaching for yield, as Becker and Ivashina, 2012, document in corporate bond markets). Following Ellul et al (2011), we use an insurer's RBC ratio as a proxy. We thus repeat the test in column (1) for insurers with very low capital, low capital and, high capital, in columns (2) to (4). We use the $10^{\text {th }}$ percentile (rounded to 5 ) and $25^{\text {th }}$ percentile (rounded to 7 ) of the RBC distribution in 2011 as cutoffs. ${ }^{36}$ The coefficient on MP-IV decreases monotonically in insurers' RBC ratios. The difference between the low and high RBC groups is statistically significant at the $10 \%$ level (the very lowest $\mathrm{RBC}$ group is small, reducing the number of observations).

Next, we introduce controls for security characteristics, including seniority, vintage, and credit rating, in order to make sure that the effect we observe is not driven by some omitted variable which insurers might base their trading behavior on. Several of the control variables enter significantly (for example, insurers tend to sell more of larger issues, perhaps reflecting liquidity). The slope on MP-IV is negative and significant again. The slope is similar to the regression with no controls, suggesting that while other factors are related to insurers' trading, they do not drive our results. In column (5), we estimate the slope separately for price and intrinsic value. Both appear with the expected sign. Notably, the coefficient on intrinsic value is highly significant, indicating again that trading behavior reflects capital requirements.

We next turn to the introduction of the new system for CMBS at year end 2010. Given the significant trading responses to RMBS, we might expect similar behavior for CMBS after new capital requirements were implemented for these assets. In column (7), there is indeed a negative coefficient on the key variable but when we include more control variables, in column (7), we find that there is no response to MP-IV for CMBS in the year. The absence of the predicted trading pattern may reflect the fact that regulatory constraints for CMBS are low to begin with (see Table 2 and Figure 3).

In conclusion, Table 4 shows that the portfolio impact of the new RMBS capital rules was substantial, and in the direction of assets with low values and low capital requirements. Any risky asset misclassified by the system as safe will be particularly attractive, and indeed, such assets seem to have become favored by the insurance industry after the new rules.

The results in Table 4 concern assets already outstanding when the new capital requirements were introduced, i.e., trading in the secondary market. Such tests of secondary market trading

\footnotetext{
${ }^{35}$ This result is consistent with Hanley and Nikolova's (2013) finding that insurers took advantage of the new capital requirements to avoid selling underwater MBS positions.

${ }^{36}$ We have also followed Ellul et al. (2013) and dropped insurers with assets below $\$ 13$ million or an RBC ratio above 50. Because we study aggregate data, these insurers have very little impact on our variables, and this variation does not affect our regressions.
} 
can be seen as joint tests of costly regulatory capital and sufficient liquidity to allow trading in the secondary market for mortgage backed securities. However, insurers tend to be buy-and-hold investors, and many of their key portfolio decisions are done when a security is issued. We next turn to this issue.

\subsection{Newly issued securities}

During the post-financial crisis period, when the reforms of capital requirements for insurers took place, RMBS issuance volumes were exceptionally low (except agency-backed RMBS, i.e., government guaranteed securities, which have very low capital requirements and very low risk), but the CMBS market revived starting in $2010 .{ }^{37}$ The volume of new CMBS is sufficient for us to compare purchases before and after the introduction of the new, low capital requirements.

The new rules for CMBS were implemented starting with 2010 capital requirements, calculated and imposed at year end 2010. Therefore, the first investment decisions that can reflect the new rules are those happening in early 2011. We examine purchases of newly issued securities during the five year period between 2008 and 2012, and look for a change starting on January, 1, 2011. Because each asset is only issued once, either before or after the reform, our test relies on comparing purchases of similar assets before and after the change. We examine the asset class for which the regulatory change occurred, i.e., non-agency MBS, as well as the other asset classes for which regulatory rules were unaffected, i.e., Corporate Bonds, Municipal Bonds, and Other Asset Backed Securities. Over our period of analysis, total purchases by insurers have a par value of $\$ 1.3$ trillion. We exclude federal government securities from the graph (since these are all investment grade), which leaves $\$ 980$ billion of private and municipal asset purchases. Since we rely on data from the NAIC, our data excludes any asset where insurers made no investment.

Our identification relies on the fact that the new rules constituted an especially large reduction in the capital requirements for riskier assets. We first use investment-grade status as a proxy for the riskiness of an asset. Overall, 92\% of insurers' asset purchases during the 2008-2011 period were investment grade. Figure 5 shows the share of aggregate insurance industry purchases of newly issued securities which were rated investment grade broken down by year and asset category. While many non-investment grade corporate and municipal bonds have been issued during this time period, insurers avoid them, both before and after 2011. Insurers' assets purchases of Other Asset Backed securities are also overwhelmingly investment grade (this category includes securitized products backed by credit card debt, auto loans, etc.). For all these categories, there is no discerning time trend in the riskiness of asset purchases. The final category, MBS, consists almost exclusively of CMBS in this period of very low private label RMBS issuance (agency RMBS is not included). The share of investment grade assets behaves differently here: prior to the capital requirement reduction, acquired CMBS securities were almost exclusively investment grade. The investment-grade share was $92 \%$ in 2009 and $94 \%$ in 2010. In dramatic contrast to asset classes which were not affected by the regulatory change, the

${ }^{37}$ For example, $\$ 15$ billion par value of private label RMBS was issued in the U.S. in 2013. This can be compared to issuance above one trillion in both 2005 and 2006. 
investment-grade share dropped precipitously after the new system was implemented for CMBS: the investment-grade share was just $47 \%$ in 2011 and $48 \%$ in 2012. Non-investment grade asset purchases, a rarity in all categories historically, have now jumped to less than half for CMBS. This result is consistent with a very large effect of the new, low capital requirements on risk taking appetite, isolated to the MBS assets affected by the new rules.

While the aggregate data clearly establish that the magnitude of the shift in investment behavior has been large, it does not adjust for the supply of securities of various credit qualities. To deal with this, we turn to cross-asset variation. For each issued security, we regress the share of an issue purchased by insurance companies on a credit quality variable and a range of other security features. There are almost 19,000 securities in the sample, across the various asset categories. We include fixed effects for each asset category and year, interacted with an indicator for High Yield (credit rating is BB+ or lower), although for brevity we do not report all the coefficients. Results are reported in Table 5. The key variable is the indicator for High Yield MBS securities issued after the new system took effect. In column (1), we include all securities that insurers bought at issue over the 2008-2012 period. The negative coefficient on the key indicator for affected, risky securities is positive and large (5.6\%). This indicates that insurers, on average, bought $5.6 \%$ more of the total amount issued of risky MBS securities, after the change took place, relative to the change in the share bought for other high yield securities. ${ }^{38}$ Since the measurement is relative to total par value, the $5.6 \%$ coefficient estimate has to be considered substantial. First, this establishes that the pattern in Figure 5 is not a mechanical function of the composition of MBS issues. Put differently, insurers have replaced other investors as buyers of newly issued high yield MBS. The other columns present several robustness tests. In column (2), we weigh securities by total size, which may be more relevant for understanding overall portfolio risk. The share of high yield securities bought by insurers increased by $9.9 \%$ when the new rules were implemented: again positive, large, and highly statistically significant. In columns (3) and (4), we repeat these equal weighted and value weighted regressions for only the 2010-2011 window (i.e., the last year of old rules and the first year of new rules for CMBS). This reduces the number of observations by around half. The point estimates are slightly larger with the narrower time window, with or without weights, and statistical significance remains strong. ${ }^{39}$

The regressions in column (1)-(4) all rely on ratings, which are imperfect measures of risk. A market-based measure of risk would be a useful complement, in order to verify that insurers' risk preferences have changed. We lack data on yields to maturity for most securities, but we have data on coupon yields for almost every issue. To the extent that higher coupons tend to be

\footnotetext{
${ }^{38}$ This is a relative finding, since we include year indicators interacted with the high yield indicator. The change is entirely taking place in the CMBS category, and not in the comparison groups (as Figure 4 also suggests).

${ }^{39}$ We have additionally tried many further variations on these tests, with very similar results. For example, we have included detailed controls (including non-parametric) for maturity and size, and for the exact type of collateral (mostly relevant for non-mortgage ABS, but also for MBS). We have also used log amount purchased instead of shares as dependent variable. The key result consistently holds across all combinations of these variations, establishing that the result is robust.
} 
associated with higher risk and higher yields, we can use this as a proxy measure of risk. ${ }^{40} \mathrm{We}$ use the coupon rate instead of the rating-based indicator as a measure of risk in columns (5) and (6). After the new rules were implemented, the coefficient on coupon yield increased by 1.4 (equal-weighted) or 3.2 (value-weighted), implying that a security with a $2 \%$ higher yield (the inter-quartile range) would see insurers buying $2.8 \%$ to $6.4 \%$ more of the issued amount, post change. These results are consistent with our previous ratings-based measure of risk-taking: after the new capital requirements, the appetite for high risk CMBS increases significantly.

Finally, we examine to what extent insurers with lower RBC ratios are important in the industry's shift of investment preferences toward low quality CMBS tranches. To examine this, we use the share of insurance companies' purchases by low RBC insurers as our dependent variable. We choose an RBC cut-off of 6 to define "low RBC". The mean of this variable is 0.535 , suggesting that roughly $50 \%$ of the industry's new purchases are made by "low RBC" insurers. The coefficient of interest is the indicator variable (MBS; Post change; High yield security). The positive and statistically significant coefficient suggest that the share bought by low RBC insurers goes up precisely for low quality MBS, relative to comparison groups, at the time when the new rules were implemented. ${ }^{41}$

Overall, the results on insurers' aggregate investment behavior in the market for new high yield securities point to a large increase in risk appetite isolated to MBS securities. Thus, aside from the direct effect the new capital requirement rules had on the amount of equity insurers have to hold, they also have an important impact on the industry's portfolio decisions. The effect is stronger for RMBS in secondary markets, but also very prominent in new issues markets which currently only have CMBS. Thus, both types of MBS are affected by the new rules. While the risk-taking effect in both markets is large relative to purchases (cf. Figure 5), we note that they are still small relative to overall insurer portfolios (cf. Table 3). However, as time goes by, insurers eventually turn over (replace) their entire balance sheet. Recall that much of the RBC for insurers comes from MBS. Thus, if the impact of the rules remains, the long run change in aggregate insurer investment risk will be substantial.

\section{Analysis of new Input: ELOSS}

While our previous analysis highlighted the implications of the new system for risk buffers and risk-taking incentives, we now turn to the narrower question whether ELOSS is a superior measure of credit risk. To this end, we test the informativeness of ELOSS in predicting defaults and losses relative to ratings to shed light on the question whether ratings can indeed be replaced by alternative risk measures, a fundamental challenge in implementing the mandate of the Dodd-Frank Act (Section 5.1). Second, we will address whether the conflicts of interests

\footnotetext{
${ }^{40}$ The coupon yield is highly correlated with issue size, with issue maturity, with credit rating at issue, and where we have the data, yield to maturity at issue.

${ }^{41}$ For space reasons, we only include the basic specification. The coefficient is larger for value weighted regressions.
} 
implied by Pimco's and BlackRock's role as institutional investors are of empirical relevance and systematically bias risk assessments of securities (Section 5.2).

\subsection{Informativeness of ELOSS}

To examine the (conditional) information content of ELOSS in predicting losses / defaults, we rely on two independent credit risk outcomes. First, following Griffin et al. (2013), we use a ratings-based default measure, which identifies securities that have transitioned into poor ratings or uncovered status. Second, we use a measure of accumulated losses from He et al. (2013). This variable measures realized losses up to year end 2012. It has the advantage of providing a ratings-independent way of measuring defaults. Both measures are imperfect and measure slightly different outcomes. The ratings-based measure will treat a security as already defaulted if it is known in advance that a security will eventually miss payments. It thus contains expectations about future outcomes. In contrast, the measure by He et al. (2013) only measures losses that have already been realized. A security that has not missed a payment yet, (but with known losses in the underlying mortgage pool) would therefore be considered a security with a zero loss. It is worthwhile recalling the default mechanics for MBS assets. When many underlying mortgages default, there is initially sufficient money to pay all coupons, and no tranches default. Indeed, foreclosure on collateral properties may mean the pool has sufficient cash, even if large losses of principal are inevitable.

In order to run a horse-race between ELOSS and ratings, we determine a proxy for expected losses based on ratings. We use the hypothetical $\mathrm{RBC}$ requirement based on ratings (see construction in Table 1), RBC (old), for three reasons. First, we want to summarize the ratingsbased measure in a single variable (rather than a fixed effect for each notch) to make it comparable to the single variable ELOSS. Secondly, we want to account for the nonlinearity of risk in the ratings scale (e.g., Hilcher and Wilson, 2013), something the RBC categorization achieves (see Table 1). Third, we want to use a transformation that is not subject to discretion. If anything, this transformation of ratings should make ratings perform "worse" relative to the continuous measure ELOSS. We have replicated our results using various alternative transformations of ELOSS and ratings, such as decile indicators for the respective variables. ${ }^{42}$

Results are reported in Table 6, where Panel A contains tests for the new risk assessments for RMBS provided by Pimco, and Panel B contains the analogous tests for CMBS provided by BlackRock. In Panel A, column (1) we regress three-year default rates of RMBS securities on their assigned ELOSS and (transformed) credit rating. We use a linear probability model (i.e., OLS). The coefficients on both risk measures are statistically significant, implying ELOSS and ratings contain some independent information about asset risk. However, ELOSS contributes much less to R-squared (see two bottom rows of the table) and has smaller economic importance: A one-standard deviation increase in ELOSS (controlling for ratings) leads to a $9 \%$ increase in the default probability, whereas a one standard deviation increase in the ratings

\footnotetext{
${ }^{42}$ The results are available upon request.
} 
measure leads to an increase of default by $26 \%{ }^{43}$ In column (2) we add a range of controls for security features and ownership, as well as the security's market price. These controls are designed to control for observable features of the assets. We also add fixed effects for vintage and maturity year (since certain mortgage vintages are known to be of particularly poor quality). This regression estimates the conditional information content of ELOSS and ratings, holding all these observed features constant. The estimated coefficient on market prices is negative and significant, i.e., market prices have predictive ability beyond what's in the risk measures or captured by the security features we measure. As before, ELOSS does predict default in these regressions, but contributes less than credit ratings to overall predictability.

These results suggest that both ELOSS and ratings are useful default predictors (explaining together almost $60 \%$ of the cross-sectional variation), but also highlight that ELOSS is not superior to traditional credit ratings. If anything, ratings are better predictors of default at the three year horizon.

In columns (3) and (4) we use realized losses by 2012 as the dependent variable, with controls and with or without fixed effects. Here, ELOSS does better in terms of predictive power than ratings, which are not statistically significant. One interpretation of this is that ELOSS essentially describes losses to date, and assumes that future losses will be very small. Thus, we might interpret the fact that ELOSS matches realized losses as a sign that they are too optimistic, which is also consistent with the fact that the intrinsic value is typically above the market price of a security (Figure 1).

In Panel B, we repeat the analysis for CMBS. Because the regulatory change took place one year later, we are limited to two year default predictions. The results are broadly consistent with the RMBS results. When predicting future defaults, both measures are statistically significant and together capture $60 \%$ of the cross-sectional variation. A one standard deviation increase in ELOSS leads to a $7 \%$ increase in default, whereas a one standard deviation increase in the ratings measure leads to a $21 \%$ increase in the default probability. ${ }^{44}$ In column (2), we add the full range of controls. Interestingly, the two measures do not only contain information above and beyond the market price, but the market price is insignificant (in column 2). Ratings continue to outperform ELOSS in terms of predictive ability.

For losses sustained to date (columns (3) and (4)), neither risk measure, nor any other variable, has much predictive ability and the $R^{2}$ is low. This might reflect the low realized losses for CMBS securities (the underlying pools have sustained some losses in the recent recession, but payment defaults have been rare). ELOSS slightly outperforms ratings.

\footnotetext{
${ }^{43}$ For the sample used in the first specification of RMBS 2009, the standard deviation of ELOSS is 0.33 and 0.12 for RBC old. These values slightly differ across specifications since the sample decomposition changes from specification to specification.

${ }^{44}$ For the sample used in the first specification of CMBS 2010, the standard deviation of ELOSS is 0.26 and that of RBC old is 0.09 .
} 
Overall, Table 6 shows that both ELOSS and ratings are useful measures of credit risk, both adding predictive power to predictive regressions. Based on our sample, we find no evidence that ELOSS is more accurate than ratings. We now turn to the question whether ELOSS might be systematically biased due to conflicts of interests of the providers.

\subsection{Determinants of ELOSS (Intrinsic value)}

Relative to credit rating agencies, whose issuer-pays business model has been heavily criticized, the potential conflicts of interests of the new providers are different. BlackRock and Pimco are themselves large investors in MBS securities, either in their own right, or on behalf of investors (including many regulated insurers). On the one hand, this means that the data providers have more expertise in evaluating the thousands of securities they have to evaluate and can provide risk assessments in a more cost-effective way. On the other hand, Pimco and BlackRock face an incentive to bias their reported ELOSS in order to profit, or allow clients to profit. Setting ELOSS to a low value reduces the insurance industry's capital requirements. For example, providing low capital requirements could support the price of securities BlackRock and Pimco hold, or even securities they currently hold but intend to sell (see Prediction 3). Of course, there are countervailing reputational incentives (the contract to provide ELOSS may not be renewed).

To examine this issue, we turn to regressions relating ELOSS to BlackRock's and Pimco's holdings of securities in Table 7. We first analyze Pimco's estimates (columns 1-2) and then turn to BlackRock's estimates (columns 3-4). In column 1, we compare the intrinsic value to the market price. The slope is a little below one (the difference from one is statistically significant), suggesting that intrinsic values assigned by Pimco are close to reported market prices. Moreover, the estimated intercept (0.29, not reported in the table), implies that the fitted regression line lies above the 45 degree line (in the relevant region between a market price of 0 and 1), as already indicated by the polynomial fit provided in Figure 1. On average, the intrinsic value is above the market value by around 0.15 .

In column 2, we include two variables reflecting Pimco's holdings: the value of holdings at year end, and the relative change in its position over the next year (log difference). ${ }^{45}$ A positive association between holdings and intrinsic values is predicted by almost any theory of Pimco's information production, and does not necessarily suggest any agency conflict. For example, it may be that Pimco mutual funds tend to invest in assets that the firm's internal models are optimistic about, and that the same information is incorporated into ELOSS. However, higher Pimco holdings do not appear related to intrinsic value. To address possible exploitation of Pimco's regulatory impact more directly, we also include a measure of future trading' in our specification. If Pimco was trying to "pump and dump" a security, we would expect to see a negative coefficient on future trading, i.e., assets that the firm intends to sell in the future are rated more highly. We find an insignificant coefficient on this measure of trading. We also include several additional control variables. A second order term for the reported market price enters with a large, negative coefficient, implying a concave relationship with intrinsic value (see

\footnotetext{
${ }^{45}$ Note that holdings includes both to assets managed on behalf of others, from mutual funds, and held on a firm's own account.
} 
Figure 1). Larger issues, and those with large insurance holdings, tend to have slightly higher intrinsic values. The latter pattern is consistent with a systematic bias in favor of those securities held by the insurance industry. Finally, assets with a high coupon rate have lower intrinsic values, as predicted based on the mechanics of intrinsic value calculations (see Equation 6 in Section 1.3). ${ }^{46}$

In Table 7, columns 3-4, we report the analysis for CMBS securities, whose intrinsic value is determined by BlackRock. BlackRock estimates zero loss for $67 \%$ of the tranches and hence an intrinsic value of 1 . Column 2 includes no control variables beyond reported market prices. The slope is positive, and less than one, as for RMBS. The constant is at 0.33 (unreported in Table 7). Therefore, the fitted values for risk assessments by BlackRock also lie above the 45 degree line (in the relevant region between a market price of 0 and 1), confirming implication 2) (see also Figure 1). However, the difference between the two is small. In column 4, we include the full set of control variables. BlackRock's holdings and future trading show a slight positive association with the intrinsic value it assigns to a security. Moreover, like Pimco, BlackRock assigns higher values to securities that are held by insurance companies. As with RMBS, securities with a high, fixed coupon rate tend to have low intrinsic values, and thus low capital requirements. This creates an incentive for insurers to systematically favor assets with low coupon rates, i.e. where most of the value comes from par repayment.

Taken together, the results in Table 7 suggest that BlackRock and Pimco do not use ELOSS to inflate prices on assets they want to sell, although we cannot reject a slight bias in favor of assets held by the regulated industry. The primary concern of using large investors as a source for risk measures, that they will exploit the system to "pump-and-dump", does not seem to be empirically prevalent. Of course, the fact that the conflict is not detectable in the current context and data sample does not rule out that it exists, or that it can be important in other settings or at other times.

\section{Conclusions}

The U.S. insurance industry provides a unique setting for analyzing the implications of "replacing ratings" in financial regulation. Our findings indicate that the switch from credit ratings to risk assessments performed by institutional investors and to capital requirements that are adjusted for book values has led to a significant decrease in aggregate capital requirements, driven in large part by treating RMBS securities as essentially riskless. Because the new capital requirements are much lower than under the previous system, and lower than those that are imposed on the same risk taking in other asset classes, one interpretation is that the new regulation reflects industry interests rather than the long term goal of financial stability. Alternatively, the rules reflect short term desire to avoid defaults and fire sales, a sort of improvised macro-prudential regulation. However, these potential benefits need to be weighed

\footnotetext{
${ }^{46}$ A very small number of tranches have floating coupon rates. We set the coupon rate variable to zero for these and include an indicator variable.
} 
against the associated long run costs: the new rules have no time limit, and therefore provide a strong incentive for insurers to take on risks preferentially in MBS going forward.

Indeed, we do find that the new capital requirements have large effects on portfolio choices, especially in the market for new securities. Generally, this is evidence that capital regulation can drive investment behavior of regulated entities and thereby affect asset demand. As long as the low, new capital requirements remain in place, the amount of systematic risk taken on can be expected to keep increasing when older, safer assets get replaced by newly issued assets of higher risk, in particular if the high-risk non-agency RMBS market revives. Thus, the long run real effects of this regulatory change may be even more pronounced than the (initial) effects we document.

\section{References}

Admati, Anat, Peter DeMarzo, Martin Hellwig, and Paul Pfleiderer, 2011: "Fallacies, irrelevant facts, and myths in the discussion of capital regulation: Why bank equity is not expensive," Working paper series, Stanford University.

Almeida, Heitor, Philippon, Thomas, 2007, "The Risk-Adjusted Cost of Financial Distress." Journal of Finance, 62, 2557-2586.

Agarwal, Sumit, David Lucca, Amit Seru, and Francesco Trebbi, 2012, "Inconsistent Regulators: Evidence From Banking", working paper.

Becker, Bo, and Ivashina, Victoria, 2012, "Reaching for yield in the bond market", forthcoming Journal of Finance.

Becker, Bo, and Milbourn, Todd, 2011, "How did increased competition affect credit ratings?" Journal of Financial Economics, 101, 493-514.

Behn, Markus, Haselmann, Rainer, and Vikrant Vig, 2014, "The limits of model-based regulation" Unpublished Working Paper.

Boyson, Nicole, Fahlenbrach, Rüdiger, and René Stulz, "Why do banks practice regulatory arbitrage? Evidence from usage of trust preferred security" NBER working paper 19,984.

Bertrand, Marianne, Duflo, Esther, and Mullainathan, Sendhil, "How much should we trust differences-in-differences estimates?", Quarterly Journal of Economics, 249-275.

Board of Governors of the Federal Reserve System, 2011, Report to the Congress on Credit Ratings, July.

Bolton, Patrick, Freixas, Xavier, and Shapiro, Joel, 2012, "The credit ratings game", Journal of Finance, 67, 85-112.

Campbell, John Y., Lettau, Martin, Malkiel, Burton G., and Xu, Yexiao, 2001, "Have individual stocks become more volatile? an empirical exploration of idiosyncratic risk," Journal of Finance, 56, 1-43.

CNBC, July, 23, 2013, "Dodd-Frank turns 3, but slew of rules are still unwritten", Kayla Tausche, Amara Omeokwe.

Coval, Joshua D., Jakub W. Jurek, and Erik Stafford, 2009, "Economic Catastrophe Bonds." American Economic Review, 99, 628-66. 
Dodd-Frank Wall Street Reform and Consumer Protection Act, 2010, Pub. L. No. 111-203, 124 Stat. 1376 (to be codified at 12 U.S.C. $\S 5301$ ).

Donald, S. G., Lang, K., 2007, "Inference with Difference-in-Differences and Other Panel Data", Review of Economics and Statistics, 89(2), May, 221-233.

Ellul, Andrew, Jotikasthira, C., and Lundblad, C.T., 2011, " Regulatory pressure and fire sales in the corporate bond market", Journal of Financial Economics, 101(3), 596-620.

Ellul, Andrew, Jotikasthira, C., Lundblad, C.T., and Yihui Wang, 2013, " Is historical cost accounting a panacea? Market stress, incentive distortions, and gains trading", working paper.

Gordy, Michael B., and Soren Willemann (2012). "Constant Proportion Debt Obligations: A Postmortem Analysis of Rating Models," Management Science, 58 (3), 476-492.

Griffin, J.M. , Nickerson, J., and Tang, D. Y., 2013, "Rating Shopping or Catering? An Examination of the Response to Competitive Pressure for CDO Credit Ratings", working paper.

Hanley, Kathleen W. and Stanislava Nikolova, 2013, "The Removal of Credit Ratings From Capital Regulation: Implications For Systemic Risk", working paper.

Harris, Milton, Opp, Christian, Opp, Marcus., 2014, " Macroprudential bank capital regulation in a competitive financial system," working paper.

He, Jie, Jun Qian and Philip E Strahan, 2013, "Does the Market Understand Rating Shopping? Predicting MBS Losses with Initial Yields", working paper.

Hilscher, Jens and Mungo Wilson, 2013, "Credit Ratings and Credit Risk: Is One Measure Enough?", working paper.

Iannotta, Giuliano, and George Pennacchi, 2012, "Bank Regulation, Credit Ratings, and Systematic Risk," working paper.

Karapiperis, Dimitris, 2012, "Financing Home Ownership: Origins and Evolution of Mortgage Securitization," NAIC CIPR white paper.

Kashyap, Anil, and Jeremy Stein, 2004, "Cyclical implications of the Basel II capital standards", Economic Perspectives, Q1/2004, 18-31.

Kim, Daesik, and Santomero, Anthony M., 1988, "Risk in Banking and Capital Regulation", Journal of Finance, Volume 43, Issue 5, pages 1219-1233, December 1988

Koijen, Ralph, S.J., and Motohiro Yogo, 2012, "The Cost of Financial Frictions for Life Insurers", NBER working paper 18,321.

Koijen, Ralph, S.J., and Motohiro Yogo, 2013, "Shadow Reinsurance", NBER working paper 19,568.

Krozsner, Randall, S., and Philip E. Strahan, 1999, "What Drives Deregulation? Economics and Politics of the Relaxation of Bank Branching Restrictions", 114(4), 1437-1467.

Leaver, Clare, 2009, "Bureaucratic Minimal Squawk Behavior: Theory and Evidence from Regulatory Agencies", American Economic Review, 99(3), 572-607.

Mathis, Jérôme, Jamie McAndrews and Jean Charles Rochet, 2009, "Rating the raters: Are reputation concerns powerful enough to discipline rating agencies?", Journal of Monetary Economics, 56, 657-674.

Moody's Investor Service, 2012, Default \& Loss Rates of Structured Finance Securities: 19932011, Special Comment", November. 
Morgan Stanley Research, 2014, "Are insurance companies buying CMBS 2.0 B-pieces?" January.

National Association of Insurance Commissioners (NAIC), 2012, "Structured Securities Project", Briefs, Letters, Mous, Testimony $\&$ Speeches, http://www.naic.org/cipr_topics/topic_structured_securities.htm.

Office of the Conptroller of the Currency, Treasury, 2012, Alternatives to the Use of External Credit Ratings in the Regulations of the OCC, Final Rule, June 4.

Olson, M, 1965, The Logic of Collective Action, Cambridge, MA, Harvard University Press.

Opp, C., Opp, M., Harris, M., 2013, "Rating agencies in the face of regulation," Journal of Financial Economics, 108, 46-61.

Ordonez, Guillermo, 2013, "Sustainable Shadow Banking", NBER working paper 9,022.

Plantin, Guillaume, 2014, "Shadow Banking and Bank Capital Regulation," working paper. Peltzman, Sam, 1976, "Toward a More General Theory of Regulation," Journal of Law and Economics, 19, 211-240.

Shleifer, Andrei and Robert W. Vishny, 1992, "Liquidation Values and Debt Capacity: A Market Equilibrium Approach," The Journal of Finance, 47, 1343-1366.

Skreta, Vasiliki, Veldkamp, Laura, 2009, "Ratings shopping and asset complexity: A theory of ratings inflation", Journal of Monetary Economics, 56, 678-695.

Stigler, George, 1971, "The theory of economic regulation," Bell Journal of Economic Management Science, 2, 3-21.

Thakor, Anjan, 2014, "Bank Capital and Financial Stability: An Economic Tradeoff or a Faustian Bargain?" forthcoming, Annual Review of Financial Economics, 2014.

Merrill, Craig, Nadauld, Taylor D., Stulz, Rene, Sherlund Shane, 2013, "Why did financial institutions sell RMBS at fire sale prices during the financial crisis?", Unpublished Working Paper.

Merton, Robert, 1995, "A Funcational Perspective of Financial Intermediation", Financial Management, 24(2), 23-41.

United States, Financial Crisis Inquiry Commission, 2011, "The Financial Crisis Inquiry Report: final report of the national commission on the causes of the financial and economic crisis in the United States", Government Printing Office.

USA Today, September, 12, 2013, "Dodd-Frank act: After 3 years, a long to-do list", Kevin McCoy.

Wall Street Journal, 2010, January 5, " Insurance Rule Adds Up to \$5 Billion --- Shift in Evaluating Risk Cuts Amount Firms Must Hold to Back Mortgage Bonds".

White, L. J.,2010. "Markets: The credit rating agencies," Journal of Economic Perspectives, 24, $211-226$. 


\section{A. Appendix}

\section{A.1. RBC Risk Sources}

\begin{tabular}{|c|c|c|c|}
\hline & Life & $\mathbf{P} \& \mathbf{C}$ & Health \\
\hline$R_{0}$ & $\begin{array}{l}\text { - Affiliate investment } \\
\text { - Off-balance sheet risk } \\
\text { - Business risk (guaranty } \\
\text { fund assessment and } \\
\text { separate account risks) }\end{array}$ & $\begin{array}{l}\text { - Affiliate investment } \\
\text { - Off-balance sheet risk }\end{array}$ & $\begin{array}{l}\text { - Affiliate investment } \\
\text { - Off-balance sheet risk }\end{array}$ \\
\hline$R_{1}$ & $\begin{array}{l}\text { - Invested asset risk (except } \\
\text { stocks) } \\
\text { - Interest rate risk } \\
\text { - Reinsurance credit risk }\end{array}$ & - Fixed income asset risk & - Invested asset risk \\
\hline$R_{2}$ & - Equity asset risk & - Equity asset risk & $\mathrm{n} / \mathrm{a}$ \\
\hline$R_{3}$ & - Insurance Risk & $\begin{array}{l}\text { - Credit risk } \\
\text { - } 50 \% \text { reinsurance risk }\end{array}$ & - Insurance risk \\
\hline$R_{4}$ & - Health provider credit risk & $\begin{array}{l}\text { - Loss reserve risk } \\
\text { - } 50 \% \text { reinsurance risk }\end{array}$ & $\begin{array}{l}\text { - Credit risk (health } \\
\text { provider, reinsurance, } \\
\text { misc. receivables) }\end{array}$ \\
\hline$R_{5}$ & $\begin{array}{l}\text { - Business risk (health } \\
\text { administrative expense risk) }\end{array}$ & $\begin{array}{l}\text { - Premium risk } \\
\text { - Growth risk }\end{array}$ & $\begin{array}{l}\text { - Business risk (health } \\
\text { administrative expense } \\
\text { risk, guaranty fund } \\
\text { assessment risk, } \\
\text { excessive growth) }\end{array}$ \\
\hline
\end{tabular}

\section{A.2. RBC Intervention Cascade}

Regulatory intervention is based on the $\mathrm{RBC}$ ratio (see Section 1.1.). The more severe the capital shortage is, the stronger the regulatory powers become. The five action levels are:

1) No Action, which means that a company's RBC ratio is at least 2

2) Company Action Level, which means that the $\mathrm{RBC}$ ratio is at least 1.5 but less than 2

3) Regulatory Action Level, which means that the RBC ratio is at least 1 but less than 1.5

4) Authorized Control Level, which means that the RBC ratio is at least 0.7 but less than 1 )

5) Mandatory Control Level, which means that the RBC ratio is less than 0.7 


\section{A.3. Bias of ELOSS}

Assume there exists a unique stochastic discount factor $\tilde{m}$ and let $\tilde{L}$ denote the stochastic realization of the loss of principal, then

$$
\operatorname{ELOSS}_{M}=\mathbb{E}(\tilde{m} \tilde{L})=\operatorname{Cov}(\tilde{m}, \tilde{L})+\mathbb{E}(\tilde{m}) \mathbb{E}(\tilde{L})
$$

Moreover, let $r_{F}$ denote the risk-free rate which satisfies $1+r_{F}=\frac{1}{\mathbb{E}(\tilde{m})}$. Since losses are expected to be high in bad aggregate states (high marginal utility), fundamental insights of asset pricing imply that $\operatorname{Cov}(\tilde{m}, \tilde{L})>0$. Thus,

$$
\operatorname{ELOSS}_{M}>\frac{\mathbb{E}(\tilde{L})}{1+r_{F}}
$$

Finally, since it is empirically true that (almost all) bonds have a coupon rate $\mathrm{c}$ that is greater than the risk-free rate, we obtain that:

$$
\operatorname{ELOSS}_{M}>\frac{\mathbb{E}(\tilde{L})}{1+r_{F}}>\frac{\mathbb{E}(\tilde{L})}{1+c}=\text { ELOSS }
$$




\section{Figure 1 - ELOSS and market price}

This graph plots Intrinsic Value (i.e., 1 - ELOSS) against market price. On the left, assets are RMBS tranches, market prices are based on insurance reports in 2009, and ELOSS is from Pimco for 2009. On the right, assets are CMBS tranches, market prices are based on insurance reports in 2010, and ELOSS is from BlackRock for 2010. The red line indicates $\mathrm{y}=\mathrm{x}$ and the orange line is a flexible polynomial fit.
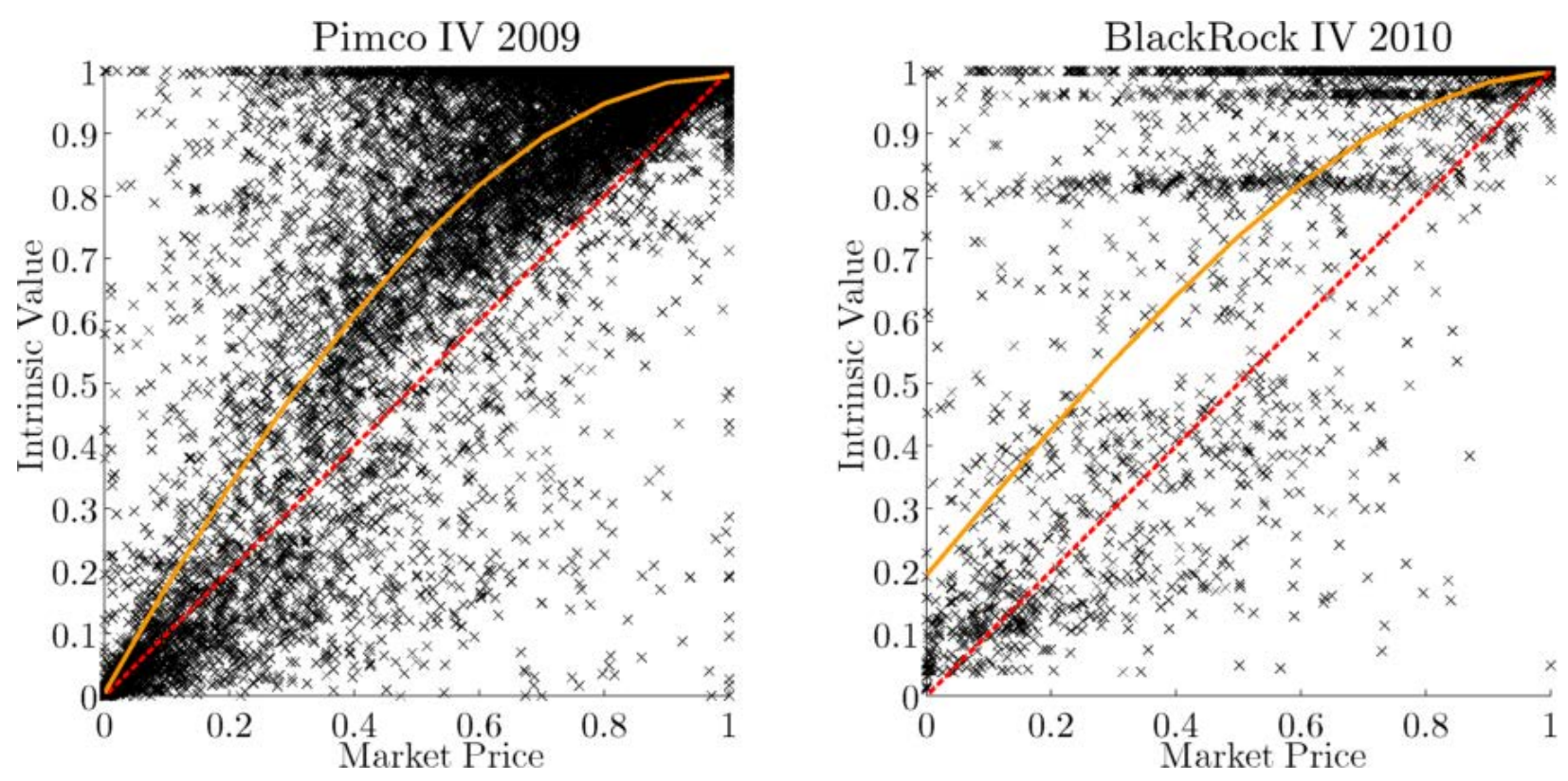
Figure 2 - Discontinuities in RBC\% for Life insurers

This graph plots the RBC\% for life insurers as a function of $(\mathrm{BV}-\mathrm{IV}) / \mathrm{BV}$. The dotted lines refer to the cutoffs for the respective NAIC 1-6 risk classification (as determined by Column 4 in Table 1). On the 45 degree line the risk-based capital requirement is given by the approximation provided in Eq. 4, i.e., $\mathrm{RBC}=\mathrm{BV}-\mathrm{IV}$.

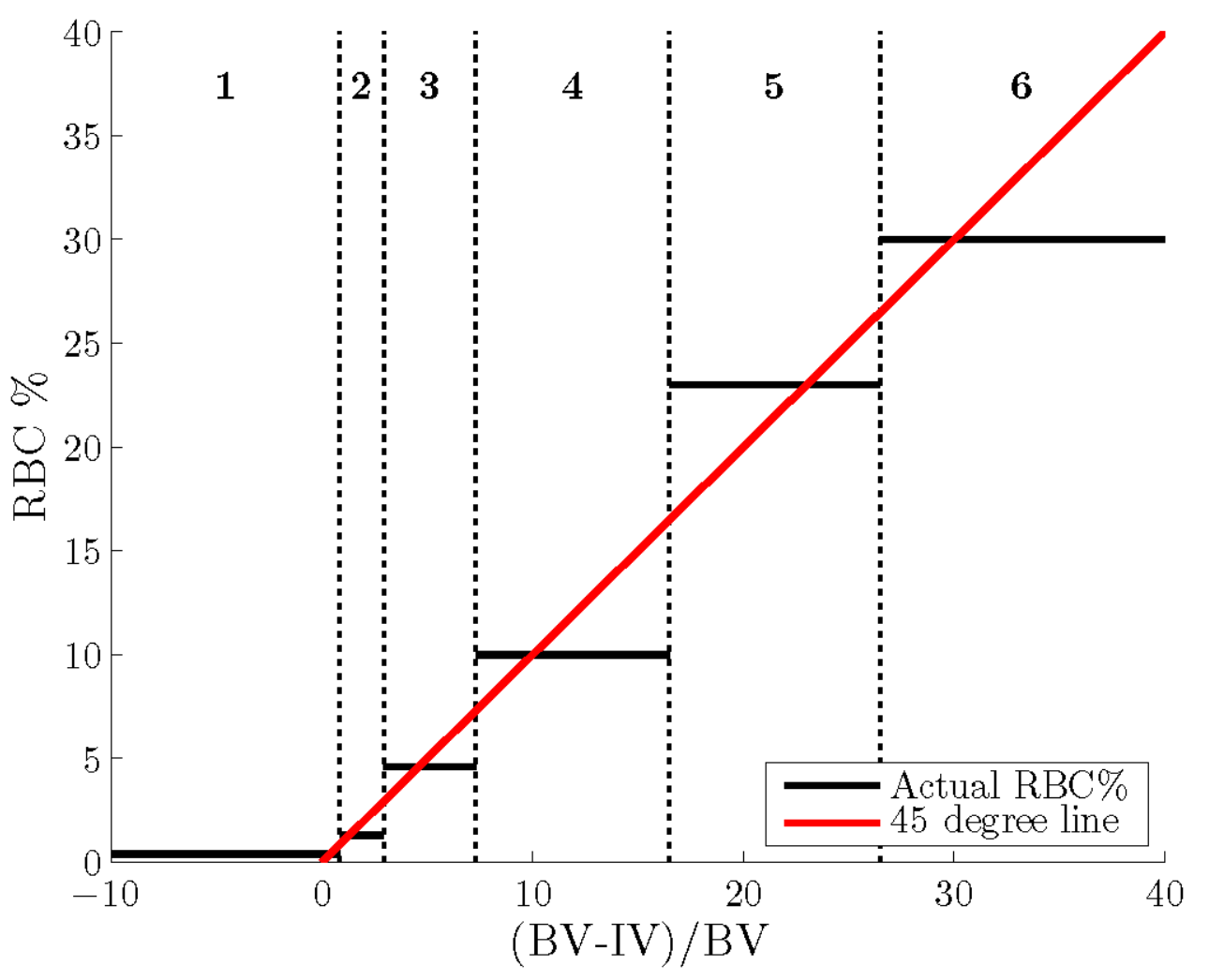


Figure 3 - Aggregate risk-based capital requirements under new and old system These graphs show capital requirements (risk based capital, RBC, scaled by book value) under new and old systems. For each year, aggregate scaled capital requirements for RMBS (left panel) and CMBS (right panel) held by the insurance industry are shown. The dotted orange line refers to the old system (and the counterfactual path if the old system had been kept). The solid black line refers to the new system. Based on NAIC reports and author calculations.
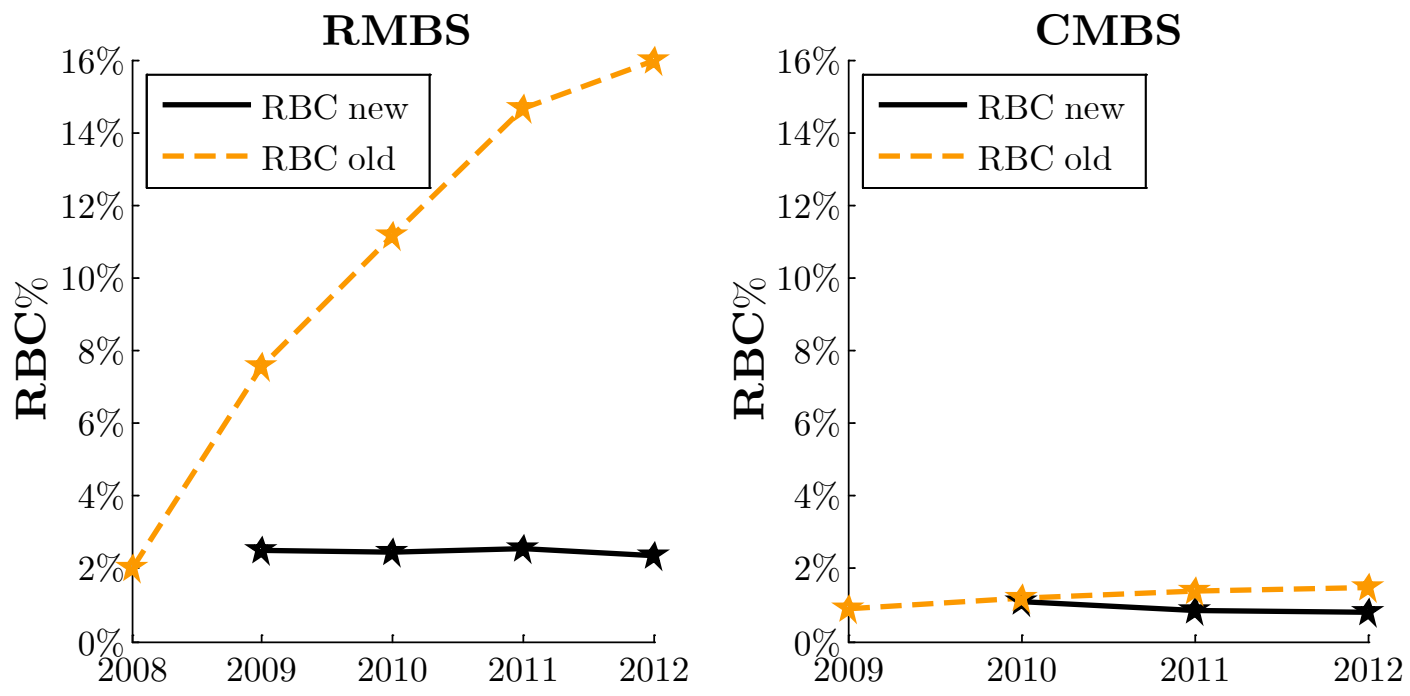
Figure 4 - NAIC risk categories and default risk for RMBS, new and old systems Figures of default rates by NAIC category for 2009 RMBS. Default is defined as downgrade to CCC or below. Figures exclude cusips where default status is ambiguous. The widths of columns indicate the book value of securities held in each category by the US insurance industry at the end of the fiscal year 2009. The heights of columns indicate three year value weighted default rates for securities in that category. The overall average default rate is $24.0 \%$. The areas of columns indicate book value of defaults.

Panel A - Three year default rates for RMBS under new system (actual)

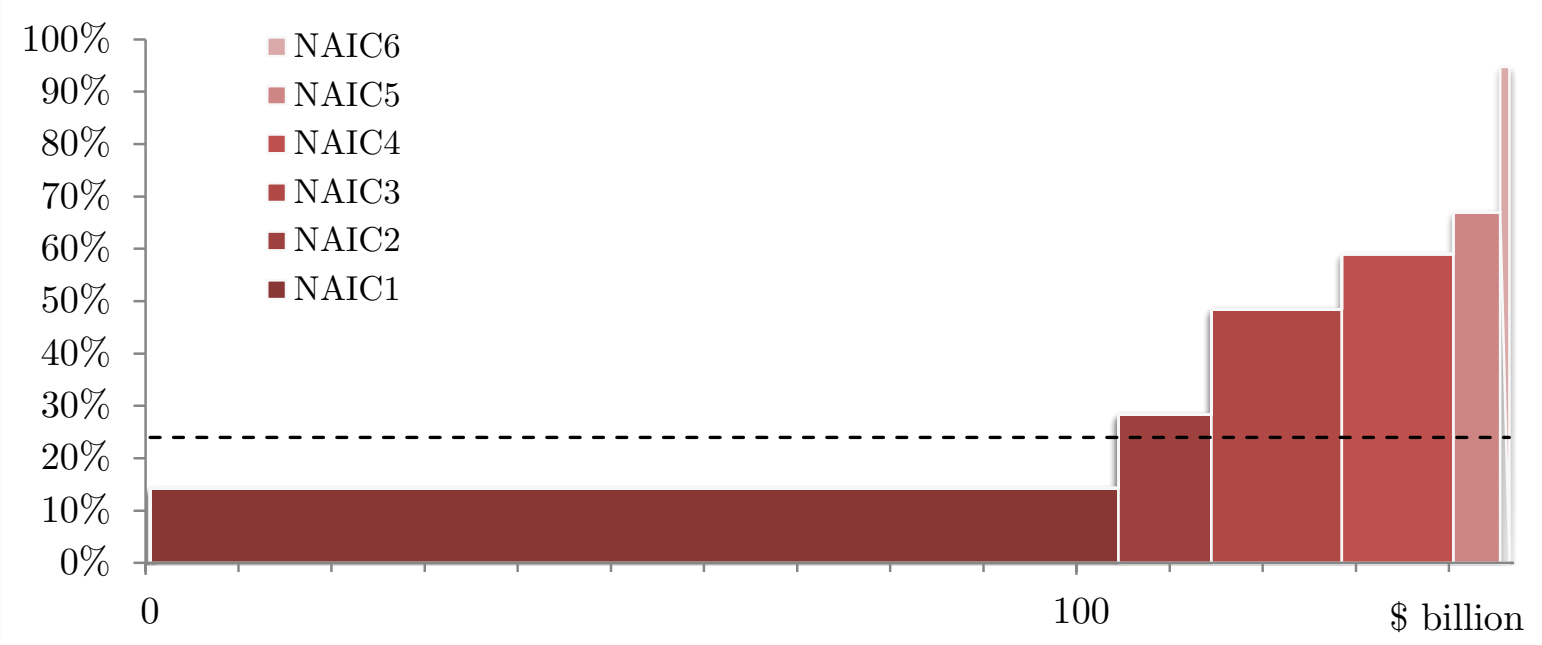

Panel B - Three year default rates for RMBS under old system (counterfactual)

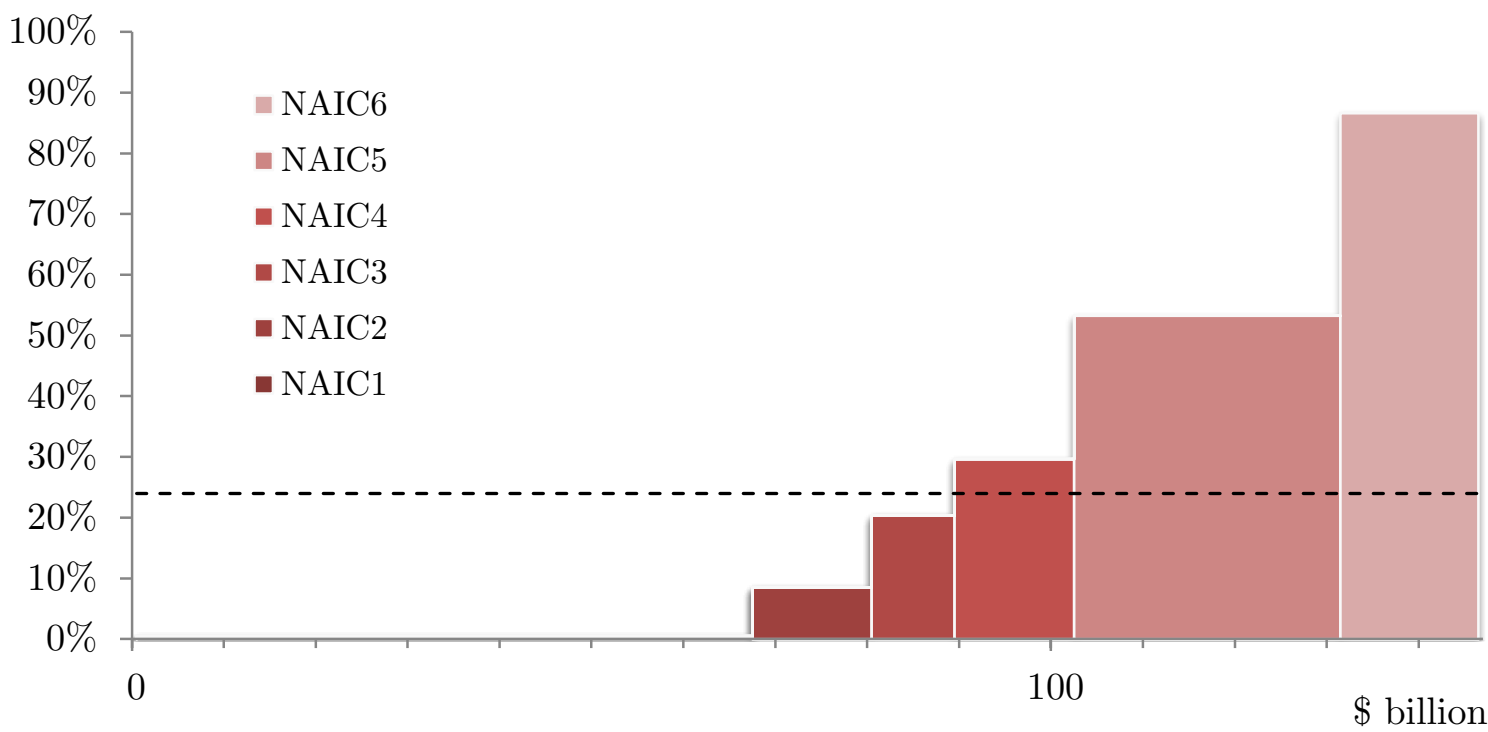


Figure 5 - Risk taking across asset classes as a function of the new system

The figure plots the composition of the insurance industry's purchases of newly issued securities 2008-2012, by asset category. Asset categories are Corporate Bonds, Municipal Bonds, MBS, Other Asset Backed (Federal Government securities are excluded). Only rated securities with a category indicated in NAIC data are included. Each graphs represents the fraction of aggregate purchases in a category (valued at par) that are rated investment grade. For expository clarity, exact values are only displayed for MBS. Total purchases of $\$ 980$ billion are reflected in the graph.

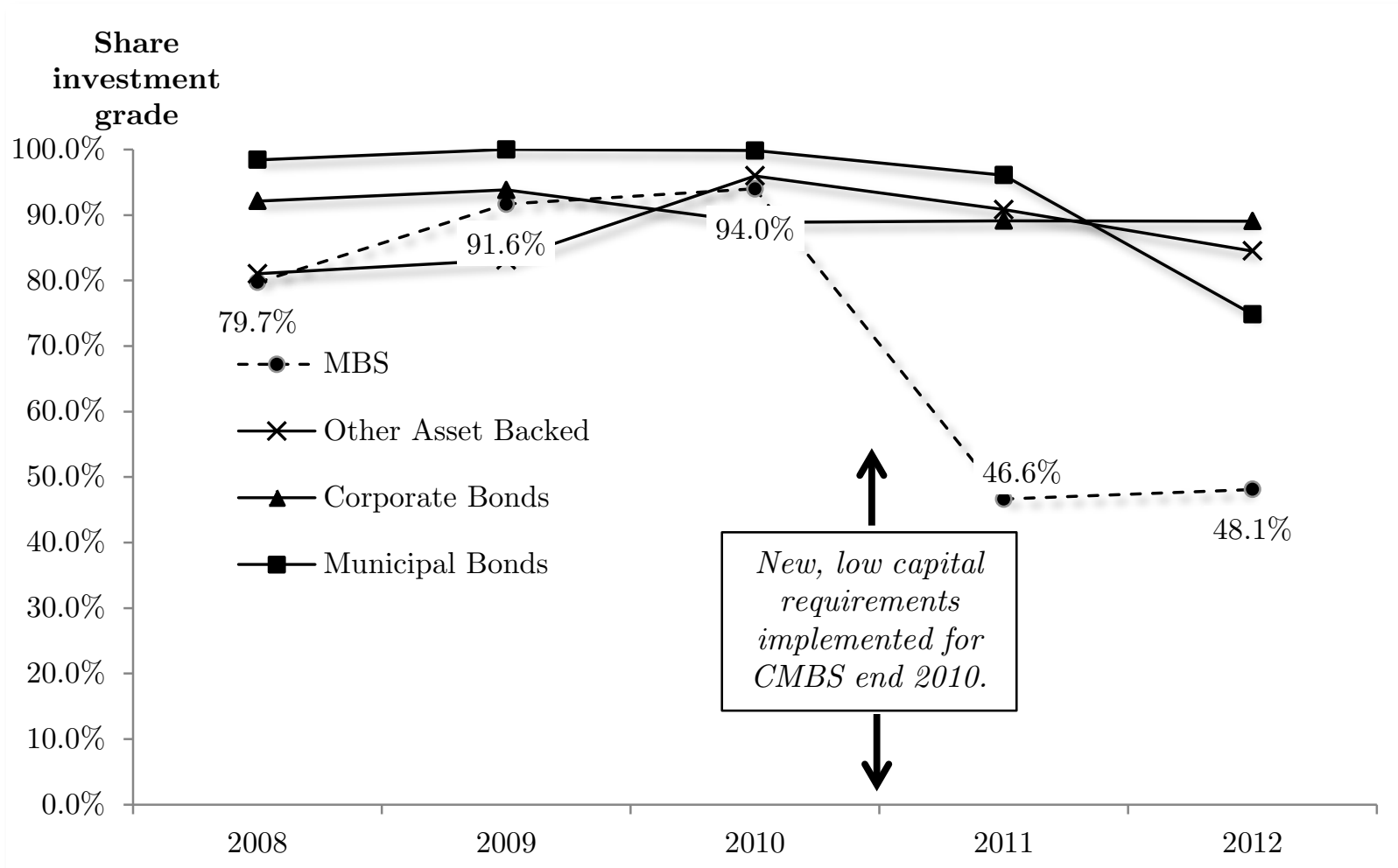


Table 1 - NAIC risk categories and risk based charges

This table shows Risk Based Capital charges (RBC\%) for mortgage-backed securities, depending on the insurer type (Life vs. P\&C) in columns 1 and 2 as well as the cutoffs for the respective risk designation under the old ratings-based regulation (column 3) and the new regulation (columns 4 and 5). The rating cutoffs in column 3 refer to the "lowest possible ratings" for which a bond still falls into a certain risk category, e.g., all bonds rated better or equal to A fall into risk category NAIC1. The cutoffs in the new system differ between life insurers and P\&C insurers (reflecting the different RBC\% charges). Fraternity insurers are subject to the same requirements as Life insurers. Health and Title insurers are subject to the same regulation as $\mathrm{P} \& \mathrm{C}$ insurers.

\begin{tabular}{|l|l|l|l|l|l|}
\hline $\begin{array}{l}\text { NAIC } \\
\text { Category }\end{array}$ & \multicolumn{2}{|c|}{ RBC\% } & Old System & \multicolumn{2}{c|}{ New System } \\
\hline & & & Rating Cutoff & \multicolumn{2}{|c|}{$\frac{\text { BV-IV }}{\text { BV Cutoff }}$} \\
\hline & Life & P\&C & & Life & P\&C \\
\hline 1 & $0.4 \%$ & $0.3 \%$ & A & $0.85 \%$ & $0.65 \%$ \\
\hline 2 & $1.3 \%$ & $1 \%$ & BBB & $2.95 \%$ & $1.5 \%$ \\
\hline 3 & $4.6 \%$ & $2 \%$ & BB & $7.30 \%$ & $3.25 \%$ \\
\hline 4 & $10 \%$ & $4.5 \%$ & B & $16.50 \%$ & $7.25 \%$ \\
\hline 5 & $23 \%$ & $10 \%$ & CCC & $26.50 \%$ & $20 \%$ \\
\hline 6 & $30 \%$ & $30 \%$ & D & & \\
\hline
\end{tabular}


Table 2 - Holdings information and aggregate RBC charges by business type and year

This table lists aggregate holdings information for all fixed income securities, RMBS and CMBS held by insurance companies for the years between 2009 and 2012. We distinguish by business type: Life, P\&C, and Other (Health, Fraternity, Title insurers). The variable BV refers to the bookadjusted carrying value (in $\$ b n$ ). The variable MV refers to the market value based on brokerage quotes (in $\$ b n$ ). RBC FI is the RBC charge for all fixed income securities (in \$bn). RBC new (old) refers to the capital charge under the new (old) system. RBC save measures the \% savings in $\mathrm{RBC}$ requirements relative to the old capital requirements ( $\mathrm{RBC}$ old) of the sub-category. $\mathrm{RBC}$ save FI relates the savings ( $\mathrm{RBC}$ new - $\mathrm{RBC}$ old) to the hypothetical RBC of the entire fixed income (FI) portfolio under the old system (RBC FI + RBC old - RBC new). The variable Share indicates the portfolio share of RMBS and CMBS, respectively.

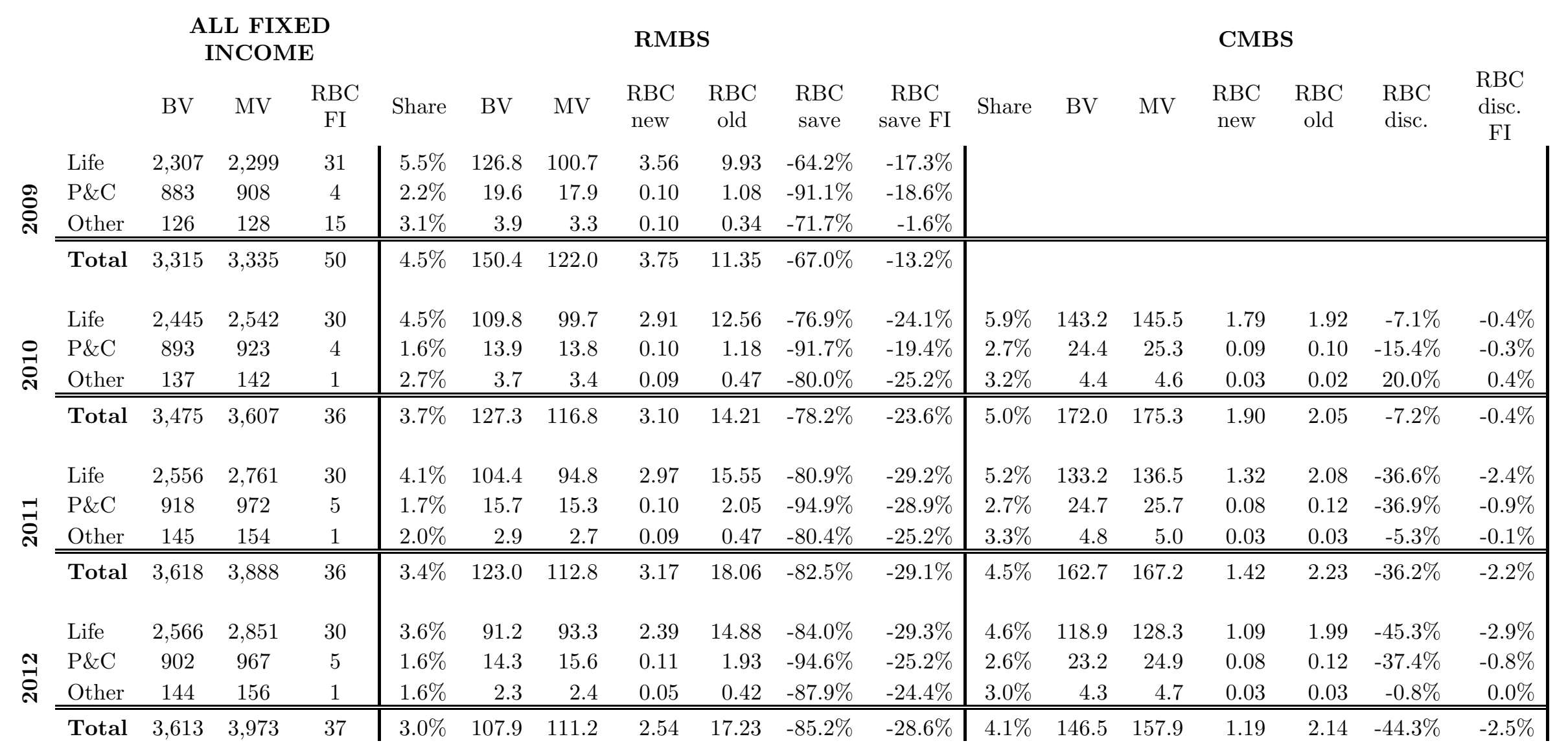




\section{Table 3 - Sample summary}

The table shows summary statistics for the sample of RMBS and CMBS securities used in the paper. Summary statistics are reported for the first year of the new regulatory regime - 2009 for RMBS and 2010 for CMBS. Insurance holdings are valued at book value. ELOSS is the credit risk measure provided by Pimco and BlackRock to the regulator for each cusip. Default is based on ratings and is defined as a current rating of D, $\mathrm{CCC}$ or CC, or for securities with no having no rating, having first had a rating of BB- or above, and subsequently a rating of CC or below. Losses by 2012, \% are from He, Qian and Strahan (2013) and is based on reported impairments by year-end 2012 (refers to 16,568 RMBS and 2,625 CMBS assets). Market prices are from insurers' accounting reports. Coverage refers to the data availability of a certain variable as represented by the total \$bn amount held by insurers in the CUSIPS with data availability.

\section{Panel A - RMBS (2009)}

\begin{tabular}{|c|c|c|c|c|c|c|c|}
\hline & $\begin{array}{c}\text { Insurance } \\
\text { holdings, } \$ \\
\text { billion }\end{array}$ & \# cusips & $\begin{array}{c}\text { Average book } \\
\text { value, \% par }\end{array}$ & $\begin{array}{l}\text { ELOSS, } \\
\% \text { par }\end{array}$ & $\begin{array}{c}\text { Default \% by } \\
2012\end{array}$ & $\begin{array}{c}\text { HQS Losses by } \\
\text { 2012, \% par }\end{array}$ & $\begin{array}{c}\text { Market price, } \\
\text { 2009, \% par }\end{array}$ \\
\hline A- to AAA & 67.0 & 8,367 & 97.8 & 0.9 & 2.8 & 0.1 & 83.4 \\
\hline $\mathrm{BBB}-$ to $\mathrm{BBB}+$ & 13.0 & 1,720 & 89.1 & 6.8 & 24.5 & 0.2 & 66.4 \\
\hline $\mathrm{BB}-$ to $\mathrm{BB}+$ & 9.3 & 1,218 & 85.1 & 10.7 & 39.2 & 0.2 & 62.2 \\
\hline B- to $\mathrm{B}+$ & 13.4 & 1,639 & 50.5 & 15.4 & 53.1 & 0.3 & 57.1 \\
\hline $\mathrm{CCC}$ or $\mathrm{CC}$ & 29.1 & 3,179 & 73.4 & 24.4 & 79.0 & 3.8 & 52.7 \\
\hline $\mathrm{C}$ or $\mathrm{D}$ & 15.2 & 4,302 & 39.9 & 61.3 & 97.3 & 36.0 & 29.4 \\
\hline Total & 147.0 & 20,425 & 80.2 & 19.5 & 39.3 & 8.5 & 63.2 \\
\hline Coverage (\$bn) & & & 147 & 147 & 146 & 124 & 147 \\
\hline
\end{tabular}

\section{Panel B - CMBS (2010)}

A- to AAA

$\mathrm{BBB}-$ to $\mathrm{BBB}+$

$\mathrm{BB}-$ to $\mathrm{BB}+$

$\mathrm{B}-$ to $\mathrm{B}+$

$\mathrm{CCC}$ or $\mathrm{CC}$

C or D

Total

Coverage (\$b)

\begin{tabular}{|c|c|c|c|c|c|c|}
\hline $\begin{array}{c}\text { Insurance } \\
\text { holdings, } \$ \\
\text { billion }\end{array}$ & \# cusips & $\begin{array}{l}\text { Average book } \\
\text { value, \% par }\end{array}$ & $\begin{array}{l}\text { ELOSS, } \\
\text { \% par }\end{array}$ & $\begin{array}{c}\text { Default \% by } \\
2012\end{array}$ & $\begin{array}{l}\text { HQS Losses by } \\
2012, \% \text { par }\end{array}$ & $\begin{array}{l}\text { Market price, } \\
2010\end{array}$ \\
\hline 144.0 & 2,776 & 102.1 & 0.7 & 0.0 & 0.0 & 100.2 \\
\hline 13.3 & 648 & 98.2 & 2.5 & 1.1 & 0.3 & 83.7 \\
\hline 6.5 & 458 & 94.2 & 10.5 & 6.8 & 0.0 & 69.8 \\
\hline 4.4 & 444 & 73.2 & 25.6 & 26.0 & 0.0 & 54.1 \\
\hline 2.2 & 414 & 51.1 & 44.8 & 44.8 & 1.0 & 40.4 \\
\hline 0.7 & 399 & 24.2 & 68.2 & 98.4 & 10.8 & 21.9 \\
\hline \multirow[t]{2}{*}{172.0} & 5,139 & 88.6 & 12.4 & 15.1 & 0.9 & 80.8 \\
\hline & & 172 & 169 & 169 & 110 & 172 \\
\hline
\end{tabular}




\section{Table 4 - The investment policy response to the new rules: existing securities}

Table of regressions explaining changes in insurance holdings from year end 2009 to year end 2010, for RMBS (column 1-6) and from year end 2010 to year end 2011 CMBS (column 7-8). The dependent variable is defined as the log change in the par value of total insurance holdings, or (in columns 3 to 5 ) log change for a subset of insurers. Very low RBC indicates a ratio below 5 in the previous year. High RBC is a ratio above 7 . Rating is a numerical variable (AAA $=28$, $\mathrm{AA}+=26, \mathrm{AA}=25$, etc.), where the median is used when a security has multiple ratings. Other variables as in Table 3 . Robust standard errors, are reported in brackets below coefficients. * indicates a coefficient different from zero at the $10 \%$ significance level, ** at the $5 \%$ level, and $* * *$ at the $1 \%$ level.

\section{Category}

(1) (2)

Insurance companies

RMBS, 2009-2010

(3) (4) (5)

(5)

(6)

All

(7)

CMBS, 2010-2011

All All

Dep. Variable

Dep. Var. mean

Market price - Intrinsic

value

RBC

\begin{tabular}{ccccccc}
\hline \multicolumn{7}{c}{ One year \% change in par value, non-defaulted securities } \\
\hline-0.210 & -0.491 & -0.220 & -0.150 & -0.192 & -0.192 & -0.131 \\
\hline$-0.571^{* * *}$ & $-0.759^{* * *}$ & $-0.653^{* * *}$ & $-0.460^{* * *}$ & $-0.569^{* * *}$ & -0.132 & $-0.238^{* * *}$ \\
$(0.022)$ & $(0.230)$ & $(0.102)$ & $(0.024)$ & $(0.037)$ & $(0.033)$ & $(0.117)$
\end{tabular}

Market price

Intrinsic value

(0.044)

$0.205^{* * *}$

(0.033)

Par at issue, log

$-0.016^{* * *} \quad-0.011^{*}$

$-0.009$

Mezzanine tranche

(0.006)

(0.006)

(0.013)

Mezanine tranche

$-0.037^{* *} \quad-0.092^{* * *}$

(0.014) (0.015)

$0.273^{* *}$

$0.059^{* * *} \quad-0.138^{* * *}$

(0.108)

Subordinated tranche

(0.022)

(0.0122)

$0.396^{* * *}$

(0.065)

Credit rating

$-0.003^{* * *} \quad 0.003^{* *}$

$-0.011^{* * *}$

$(0.001) \quad(0.001)$

(0.003)

Issue year FE

Maturity year FE

R-squared

\begin{tabular}{cc}
- & - \\
- & - \\
0.045 & 0.026 \\
11,437 & 538 \\
\hline
\end{tabular}

-
-
0.025
1,096

$\begin{array}{cc}- & \text { Yes } \\ - & \text { Yes } \\ 0.037 & 0.054 \\ 8,561 & 6,136\end{array}$

Yes
Yes
0.066
6,136

$\begin{array}{cc}\text { Yes } & \text { Yes } \\ \text { Yes } & \text { Yes } \\ 0.007 & 0.101 \\ 3,557 & 1,684\end{array}$




\section{Table 5 - The investment policy response to the new rules: new issues}

Table of regressions explaining the share of a newly issued security purchased by insurance companies, 2008-2012. The dependent variable in columns (1) to (6) is insurance holdings at end of the year when a security is first issued, as a share of the security's total par value. In column (7), the dependent variable is the share of total life insurance purchases that are made by insurers with a RBC ratio below 6 . Securities with no credit rating or where the dependent variable exceeds one (indicating data error) are excluded. Ratings are based on S\&P, Moody's and Fitch. When a security is rated by two firms, the lower rating is used, and when rated by three, the median. MBS High Yield is an indicator for MBS issued with a rating of BB+ or lower, and Other High Yield is a similar indicator for other assets. Post is an indicator for securities issued in 2011 and 2012. Robust standard errors are reported in brackets below coefficients. * indicates a coefficient different from zero at the $10 \%$ significance level, ${ }^{* *}$ at the $5 \%$ level, and ${ }^{* * *}$ at the $1 \%$ level.

\begin{tabular}{|c|c|c|c|c|c|c|c|}
\hline \multirow{2}{*}{ Dep. Variable } & (1) & $(2)$ & $(3)$ & $(4)$ & $(5)$ & $(6)$ & \multirow{3}{*}{$\begin{array}{c}(7) \\
\text { Low RBC } \\
\text { share } \\
2010-11\end{array}$} \\
\hline & \multicolumn{6}{|c|}{ Share of new issue bought by insurers } & \\
\hline Period & $2008-12$ & $2008-12$ & 2010-11 & $2010-11$ & $2008-12$ & $2008-12$ & \\
\hline Dep. Var. mean & 0.148 & 0.039 & 0.130 & 0.037 & 0.148 & 0.040 & 0.535 \\
\hline $\begin{array}{l}\text { Indicator(MBS; Post change; } \\
\text { High yield security) }\end{array}$ & $\begin{array}{c}0.056^{* * *} \\
(0.014)\end{array}$ & $\begin{array}{c}0.099 * * * \\
(0.032)\end{array}$ & $\begin{array}{l}0.094^{* *} \\
(0.040)\end{array}$ & $\begin{array}{c}0.127^{* * *} \\
(0.028)\end{array}$ & & & $\begin{array}{l}0.013^{*} \\
(0.007)\end{array}$ \\
\hline $\begin{array}{l}\text { Indicator(MBS; Post change) } \\
\text { * coupon yield }\end{array}$ & & & & & $\begin{array}{c}1.363^{* * *} \\
(0.450)\end{array}$ & $\begin{array}{c}3.169^{* * *} \\
(0.701)\end{array}$ & \\
\hline Weights & - & Size & - & Size & - & Size & - \\
\hline $\begin{array}{l}\text { Issue year * High Yield } \\
\text { indicator FE }\end{array}$ & Yes & Yes & Yes & Yes & - & - & Yes \\
\hline $\begin{array}{lccc}\text { Category } & * & \text { High } & \text { Yield } \\
\text { indicator } & \text { FE } & & \end{array}$ & Yes & Yes & Yes & Yes & - & - & Yes \\
\hline Issue year $\mathrm{FE} *$ coupon yield & - & - & - & - & Yes & Yes & - \\
\hline Category FE $*$ coupon yield & - & - & - & - & Yes & Yes & - \\
\hline R-squared & 0.096 & 0.167 & 0.116 & 0.190 & 0.089 & 0.164 & 0.252 \\
\hline $\mathrm{N}$ & 18,813 & 18,813 & 8,334 & 8,334 & 18,419 & 18,419 & 10,795 \\
\hline
\end{tabular}


Table 6 - Default risk: ELOSS vs. Ratings

Regression of RMBS (Panel A) and CMBS (Panel B) defaults on various security features. Default is defined as downgrade to CCC or below. ELOSS is the expected loss assigned to a security under the new system for capital requirements. $\mathrm{RBC}$ (old) is the counterfactual capital requirement that would have prevailed if the ratings-based system had been maintained. The market price is based on the contemporaneous fair value reported in the insurers' accounting reports. Insurance holdings are measured at book value, year-end 2009. Par at issue is the amount of face value of the security when first issued. Mezzanine and subordinated tranches are identified based on Moody's classifications. Other variables as defined in Table 3. Robust standard errors are reported in brackets below coefficients. ${ }^{*}$ indicates a coefficient different from zero at the $10 \%$ significance level, ${ }^{* *}$ at the $5 \%$ level, and $* * *$ at the $1 \%$ level.

\section{Panel A - RMBS (2009)}

\begin{tabular}{|c|c|c|c|c|}
\hline Dep. Variable & $\begin{array}{c}(1) \\
\text { Default by } \\
2012\end{array}$ & $\begin{array}{c}(2) \\
\text { Default by } \\
2012\end{array}$ & $\begin{array}{c}(3) \\
\text { HQS } \\
\text { Losses by } \\
2012\end{array}$ & $\begin{array}{c}(4) \\
\text { HQS } \\
\text { Losses by } \\
2012\end{array}$ \\
\hline Dep. Var. Mean & 0.377 & 0.415 & 0.086 & 0.056 \\
\hline ELOSS & $\begin{array}{c}0.354^{* * *} \\
(0.013)\end{array}$ & $\begin{array}{c}0.301^{* * *} \\
(0.024)\end{array}$ & $\begin{array}{c}0.438^{* * *} \\
(0.010)\end{array}$ & $\begin{array}{c}0.316^{* * *} \\
(0.014)\end{array}$ \\
\hline Ratings / RBC (old) & $\begin{array}{c}2.591^{* * *} \\
(0.030)\end{array}$ & $\begin{array}{c}1.993^{* * * *} \\
(0.052)\end{array}$ & $\begin{array}{c}0.005 \\
(0.012)\end{array}$ & $\begin{array}{l}-0.016 \\
(0.018)\end{array}$ \\
\hline Market price & & $\begin{array}{c}-0.210^{* * *} \\
(0.025)\end{array}$ & & $\begin{array}{c}0.049 * * * \\
(0.008)\end{array}$ \\
\hline Insurance holdings, log & & $\begin{array}{c}0.006^{* * *} \\
(0.002)\end{array}$ & & $\begin{array}{c}-0.011^{* * *} \\
(0.001)\end{array}$ \\
\hline Par at issue, log & & $\begin{array}{c}-0.031^{* * *} \\
(0.003)\end{array}$ & & $\begin{array}{c}-0.011^{* * *} \\
(0.001)\end{array}$ \\
\hline Mezzanine tranche & & $\begin{array}{c}-0.051^{* * *} \\
(0.010)\end{array}$ & & $\begin{array}{l}0.009^{*} \\
(0.005)\end{array}$ \\
\hline Subordinated tranche & & $\begin{array}{l}-0.011 \\
(0.017)\end{array}$ & & $\begin{array}{c}0.015 \\
(0.012)\end{array}$ \\
\hline Issue year FE & - & Yes & - & Yes \\
\hline Maturity year FE & - & Yes & - & Yes \\
\hline R-squared & 0.565 & 0.559 & 0.445 & 0.399 \\
\hline $\mathrm{N}$ & 16,776 & 9,057 & 14,406 & 8,140 \\
\hline F-test: $\beta_{\mathrm{ELOSS}}=\beta_{\mathrm{RBC}}$ & $2,904.1^{* * *}$ & $662.9^{* * *}$ & $528.3^{* * *}$ & $136.6^{* * *}$ \\
\hline Partial R-squared: ELOSS & 0.025 & 0.008 & 0.245 & 0.074 \\
\hline Partial R-squared: RBC & 0.219 & 0.095 & 0.009 & 0.001 \\
\hline
\end{tabular}




\begin{tabular}{|c|c|c|c|c|}
\hline \multicolumn{5}{|c|}{ Panel B - CMBS (2010) } \\
\hline \multirow{3}{*}{ Dep. Variable } & (1) & (2) & (3) & (4) \\
\hline & Default & & HQS & HQS \\
\hline & by 2012 & by 2012 & $\begin{array}{c}\text { Losses by } \\
2012\end{array}$ & $\begin{array}{c}\text { Losses by } \\
2012\end{array}$ \\
\hline Dep. Var. Mean & 0.133 & 0.133 & 0.007 & 0.006 \\
\hline \multirow[t]{2}{*}{ ELOSS } & $0.272^{* * *}$ & $0.281^{* * *}$ & $0.035^{*}$ & $0.040^{* *}$ \\
\hline & $(0.039)$ & $(0.068)$ & $(0.018)$ & $(0.017)$ \\
\hline \multirow[t]{2}{*}{ Ratings / RBC (old) } & $2.358^{* * *}$ & $2.385^{* * *}$ & $0.149^{* * *}$ & 0.023 \\
\hline & $(0.105)$ & $(0.189)$ & $(0.044)$ & $(0.031)$ \\
\hline \multirow[t]{2}{*}{ Market price } & & 0.012 & & -0.013 \\
\hline & & $(0.055)$ & & $(0.009)$ \\
\hline \multirow[t]{2}{*}{ Insurance holdings, log } & & $-0.009 * *$ & & $-0.007^{* *}$ \\
\hline & & $(0.004)$ & & $(0.003)$ \\
\hline \multirow[t]{2}{*}{ Par at issue, $\log$} & & $0.016^{* * *}$ & & $0.009^{* * *}$ \\
\hline & & $(0.006)$ & & $(0.003)$ \\
\hline \multirow[t]{2}{*}{ Mezzanine tranche } & & 0.001 & & 0.003 \\
\hline & & $(0.013)$ & & $(0.004)$ \\
\hline \multirow[t]{2}{*}{ Subordinated tranche } & & 0.013 & & $0.010^{* *}$ \\
\hline & & $(0.015)$ & & $(0.005)$ \\
\hline Issue year FE & - & Yes & - & Yes \\
\hline Maturity year FE & - & Yes & - & Yes \\
\hline R-squared & 0.603 & 0.643 & 0.072 & 0.180 \\
\hline $\mathrm{N}$ & 4,987 & 2,149 & 2,120 & 1,537 \\
\hline F-test: $\beta_{\mathrm{ELOSS}}=\beta_{\mathrm{RBC}}$ & $230.0^{* * *}$ & $80.5^{* * *}$ & $4.08^{* *}$ & 0.17 \\
\hline Partial R-squared: ELOSS & 0.016 & 0.009 & 0.004 & 0.004 \\
\hline Partial R-squared: RBC & 0.114 & 0.097 & 0.010 & 0.000 \\
\hline
\end{tabular}


Table 7 - Explaining intrinsic value

Regression of RMBS (column 1-2) and CMBS (column 3-4) intrinsic values (one minus the ELOSS assigned by BlackRock and Pimco). Independent variables include various security features and Pimco's (col. 1-2) and BlackRock's (col. 3-4) positions in each asset (log of the $\$$ par value held in own accounts or accounts managed for others). Net trade refers to the change in position over the next year, as a fraction of par. Floating coupon is an indicator variable for floating coupon rate securities. Coupon rate is set to zero for floaters. Other variables as defined in Tables 4 and 5. Robust standard errors are reported in brackets below coefficients. * indicates a coefficient different from zero at the $10 \%$ significance level, $* *$ at the $5 \%$ level, and $* * *$ at the $1 \%$ level.

\begin{tabular}{|c|c|c|c|c|}
\hline \multirow{4}{*}{$\begin{array}{l}\text { Asset category } \\
\text { Firm } \\
\text { Dep. Variable }\end{array}$} & \multicolumn{2}{|l|}{ (1) } & $(3)$ & (4) \\
\hline & \multicolumn{2}{|c|}{ RMBS (2009) } & \multicolumn{2}{|c|}{ CMBS (2010) } \\
\hline & & & & \\
\hline & Intrinsic $\mathrm{v}$ & - ELOSS) & Intrinsic value & LOSS) \\
\hline Dep. Var. Mean & 0.819 & 0.862 & 0.878 & 0.896 \\
\hline Market price & $\begin{array}{c}0.838^{* * *} \\
(0.006)\end{array}$ & $\begin{array}{c}1.620^{* * *} \\
(0.070)\end{array}$ & $\begin{array}{c}0.678^{* * *} \\
(0.012)\end{array}$ & $\begin{array}{c}0.634^{* * *} \\
(0.142)\end{array}$ \\
\hline Market price, squared & & $\begin{array}{c}-1.018^{* * *} \\
(0.050)\end{array}$ & & $\begin{array}{c}-0.200^{* *} \\
(0.099)\end{array}$ \\
\hline $\begin{array}{l}\text { Market price, lagged } \\
\text { one year }\end{array}$ & & $\begin{array}{l}0.032^{*} \\
(0.019)\end{array}$ & & $\begin{array}{l}-0.028 \\
(0.033)\end{array}$ \\
\hline $\begin{array}{l}\text { Pimco or BlackRock } \\
\text { holdings (log) }\end{array}$ & & $\begin{array}{l}-0.000 \\
(0.001)\end{array}$ & & $\begin{array}{c}0.004^{* * *} \\
(0.001)\end{array}$ \\
\hline $\begin{array}{l}\text { Pimco or BlackRock net } \\
\text { trade, next } 4 \text { quarters }\end{array}$ & & $\begin{array}{l}0.046 \\
(0.138)\end{array}$ & & $\begin{array}{l}0.561^{* *} \\
(0.214)\end{array}$ \\
\hline Insurance holdings, log & & $\begin{array}{c}0.009^{* * *} \\
(0.001)\end{array}$ & & $\begin{array}{c}0.022^{* * *} \\
(0.003)\end{array}$ \\
\hline Par at issue, log & & $\begin{array}{c}0.007^{* * *} \\
(0.002)\end{array}$ & & $\begin{array}{c}-0.023^{* * *} \\
(0.003)\end{array}$ \\
\hline Mezzanine tranche & & $\begin{array}{l}-0.003 \\
(0.012)\end{array}$ & & $\begin{array}{l}-0.007 \\
(0.008)\end{array}$ \\
\hline Subordinated tranche & & $\begin{array}{l}-0.017 \\
(0.016)\end{array}$ & & $\begin{array}{c}0.031^{* * *} \\
(0.009)\end{array}$ \\
\hline Floating coupon & & $\begin{array}{c}0.037 \\
(0.025)\end{array}$ & & $\begin{array}{c}-0.072^{* * *} \\
(0.003)\end{array}$ \\
\hline Coupon rate & & $\begin{array}{c}-0.028^{* *} \\
(0.011)\end{array}$ & & $\begin{array}{c}-0.012^{* * *} \\
(0.003)\end{array}$ \\
\hline Issue year FE & - & Yes & - & Yes \\
\hline Maturity year FE & - & Yes & - & Yes \\
\hline Rating notch FE & - & Yes & - & Yes \\
\hline R-squared & 0.628 & 0.732 & 0.623 & 0.788 \\
\hline $\mathrm{N}$ & 18,385 & 4,397 & 4,920 & 2,026 \\
\hline
\end{tabular}

